\title{
Structure and Expression of the C3 Gene*
}

\author{
George Fey ${ }^{1}$, Horst Domdey ${ }^{2}$, Karin Wiebauer ${ }^{3}$, Alexander S. Whitehead ${ }^{4}$, and \\ Karel Odink ${ }^{5}$ \\ ${ }^{1}$ Department of Immunology, Research Institute of Scripps Clinic, La Jolla, California 92037, USA \\ ${ }^{2}$ Division of Biology, California Institute of Technology, Pasadena, California 91125, USA \\ ${ }^{3}$ Department of Human Genetics, University of Michigan Medical School, Ann Arbor, Michigan 48109, \\ USA \\ ${ }^{4}$ Department of Medicine, Children's Hospital Medical Center, Division of Cell Biology, Boston, \\ Massachusetts 02115, USA \\ ${ }^{5}$ Wellcome Research Laboratories, Langley Court, Beckenham, Kent BR3 3BS, United Kingdom
}

\section{Introduction}

II. Structure of the $\mathrm{C3}$ Gene

\section{A. The Mouse C3 Gene}

1. Properties of Mouse $\mathrm{C} 3 \mathrm{mRNA}$

2. Cloning and Sequence Analysis of Mouse C3 cDNA

3. Structure and Characteristics of the Mouse C3 Gene

4. C3 Allotypes and Chromosomal Location of the C3 Gene

B. The Human C3 Gene

1. Preparation of Cloned Human C3 DNA Probes

2. Polymorphic Variants of the $\mathrm{C} 3$ Gene

3. Chromosomal Location of the Human C3 Gene

4. A Family Presenting Inherited C3 Deficiency

III. Expression of the $\mathrm{C3}$ Gene

A. Tissue Specific Expression

B. Induction of C3 Synthesis in Acute Inflammation

C. Involvement of Hormones in the Control of $C 3$ Production

IV. Summary

V. Acknowledgements

VI. References

\footnotetext{
* This is publication number 2989-IMM from the Department of Immunology, Scripps Clinic and Research Foundation, 10666 North Torrey Pines Road, La Jolla, California, 92037

Abbreviations: $\mathrm{C2}, \mathrm{C} 3, \mathrm{C} 4$ second, third, and fourth components of complement; $C 3 a, C 3 b, C 3 \alpha, C 3 \beta$ fragments and subunits of $\mathrm{C} 3$ abbreviated according to the Bulletin of the World Health Organization (1968) 39:935; proC3 precursor polypeptide of C3; $c D N A$ complementary DNA; $m R N A$ messenger RNA; $k b$ kilobases; $c M$ centimorgans; $R F L P$ restriction fragment length polymorphism; $S D S$ sodium dodecyl sulfate Offprint requests to: G. Fey, Department of Immunology, Research Institute of Scripps Clinic, La Jolla, California 92037, USA
} 


\section{Introduction}

The third component of complement, $\mathrm{C}$, plays an important role in the defense of mammalian organisms against microbial, fungal, viral, and parasitic infections. In addition, $\mathrm{C} 3$ and $\mathrm{C} 3$-derived peptides participate in inflammatory and immune regulatory reactions. The physiologic functions of $\mathrm{C} 3$ and of the complement system have been extensively reviewed $[48,67,78,82,104]$. This chapter deals exclusively with the molecular structure of the $\mathrm{C} 3$ gene and the control of its expression. There are several reasons to study these issues. First, the $\mathrm{C} 3$ gene provides a good model system in which to investigate eucaryotic gene expression. C3 is synthesized in a tissue-specific fashion, and its production is subject to regulation during acute inflammation. Second, inherited C3 deficiencies have been described in man and higher animals and, from studying the structure and expression of the normal and defective genes, the molecular basis of these deficiencies may be determined. Third, the biochemical properties of the $\mathrm{C} 3$ protein and its peptide derivatives and the physiologic effects of their interactions with other complement proteins, regulatory proteins, and cellular receptors must be understood in greater detail than is now possible. The analysis of C3 messenger RNA (mRNA), complementary DNA (cDNA), and the $\mathrm{C} 3$ gene will add to our comprehension of these properties.

One of the striking characteristics of the $\mathrm{C} 3$ protein is its capacity to interact specifically with a variety of other polypeptides: (a) It is the substrate for proteolytic cleavage at a single site by the $\mathrm{C} 3$ convertases of the classical and alternative pathways of complement activation. (b) It is one of the constituents of the classical and alternative $\mathrm{C} 5$ convertases and of the alternative pathway $\mathrm{C} 3$ convertase. (c) It interacts with the regulatory proteins I (C3b-inactivator) and $\mathrm{H}(\beta 1 \mathrm{H})$ that participate in the first specific steps of the catabolism of $\mathrm{C} 3$. (d) It is a ligand for several $\mathrm{C} 3$ receptor proteins on the surfaces of different cell types (see chapters by R.D. Schreiber [89] and by D.T. Fearon [35] in this volume). (e) It is modified by glycosyl transferases, a signal-peptidase, and one or several as yet unidentified enzymes that cleave the precursor polypeptide, proC3, at specific sites to generate the mature $\alpha$ and $\beta$ subunits of $\mathrm{C} 3$.

The main unresolved problem in the biochemical analysis of this protein is to determine the positions of the individual interactive sites with respect to its primary amino acid sequence and tertiary structure. The complete amino acid sequence of $\mathrm{C} 3$ is unknown, however, several groups of investigators are currently working on the sequence determination.

This chapter will begin with a description of selected properties of C3 mRNA and the producion and identification of $\mathrm{C} 3$ cDNA clones. A summary of information about functionally important domains of the polypeptide derived from cDNA sequences follows, and finally we review our current knowledge of the gene and its expression. 


\section{Structure of the C3 Gene}

\section{A. The Mouse C3 Gene}

1) Properties of Mouse C3 $m R N A$. The liver is the principal site of C3 synthesis in mice, man, and other mammals. Extrahepatic synthesis occurs mainly in macrophages and monocytes and to a lesser extent in fibroblasts, gut epithelial cells, and a few other cell types of the lymphoid and the reticuloendothelial systems [21, $23,24,36,94,108,109]$. It has been reported that $1 \%$ of total intracellular radiolabeled protein from primary tissue cultures of guinea pig liver cells is immunoprecipitable with anti-C3 sera. Also, $0.2 \%$ of the total protein synthesized in a cell-free translation system primed with liver mRNA reacted with $\mathrm{C} 3$ antisera [16]. From these data it may be estimated that the abundance of C3 mRNA in rodent liver should be on the order of $0.2 \%$ to $1 \%$. This estimation assumes an equal translation efficiency for all mRNA species and an efficient immunoreactivity of the translation products. The minimum size of $\mathrm{C} 3 \mathrm{mRNA}$ may be approximated from the length of the precursor polypeptide proC3. With a molecular weight of 170000 for the intracellular guinea pig pro C3 [16] and 175000 for the cell-free translation product from mouse liver mRNA, a minimum size of 5000 nucleotides was estimated for mouse C3 mRNA [75]. The length of mouse C3 mRNA has been determined in several ways by using cloned cDNA probes; the result is a size of 5100 \pm 200 nucleotides, including a poly A tail with a mean length of 170 nucleotides [31]. C3 mRNAs from mouse macrophages and from rat livers were both shown to be of this size [74]. Based on the frequency of C3 clones in a cDNA library prepared from murine livers, the abundance of $\mathrm{C} 3 \mathrm{mRNA}$ is on the order of $0.2 \%$ to $0.3 \%$, in accordance with the estimates derived above [31]. However, the relative abundance has not been measured precisely with quantitative RNA/DNA hybridization techniques and cloned probes.

2) Cloning and Sequence Analysis of Mouse C3 $c D N A$. A library of mouse liver cDNA was prepared in the plasmid vector pBR322 and propagated in Escherichia coli by using standard technology. The resulting library represents mRNA species of the size class 5000 nucleotides and longer. C3 cDNA clones were identified in this library by using hybrid promoted translation (hybrid selection of mRNA) [75]. The identity of $\mathrm{C} 3$ clones was confirmed by partial cDNA sequence analysis and comparison of the derived amino acid sequences with known protein sequence data from selected regions of rat, guinea pig, porcine, and human C3 [31]. The inserts carried by eight different cDNA clones represented partially overlapping sequences, beginning with the $3^{\prime}$ end and extending over a continuous stretch of 4600 nucleotides of the C3 mRNA. The $5^{\prime}$ end and the adjacent approximately 350 nucleotides of the mRNA were not represented in this library. These cDNA clones and the location of their insert sequences relative to the mRNA and the polypeptide chains are shown in Fig. 1. Sequences corresponding to a region close to the $5^{\prime}$ end of the mRNA are given in Fig. 2. The sequence was later extended beyond the region cloned in primer extension experiments [31]. From a comparison of the derived amino acid sequence with the published sequences of the $\mathrm{NH}_{2}$-termini of the guinea-pig and human $C 3 \beta$ subunits $[42,96,98]$, this region appears to encode the 

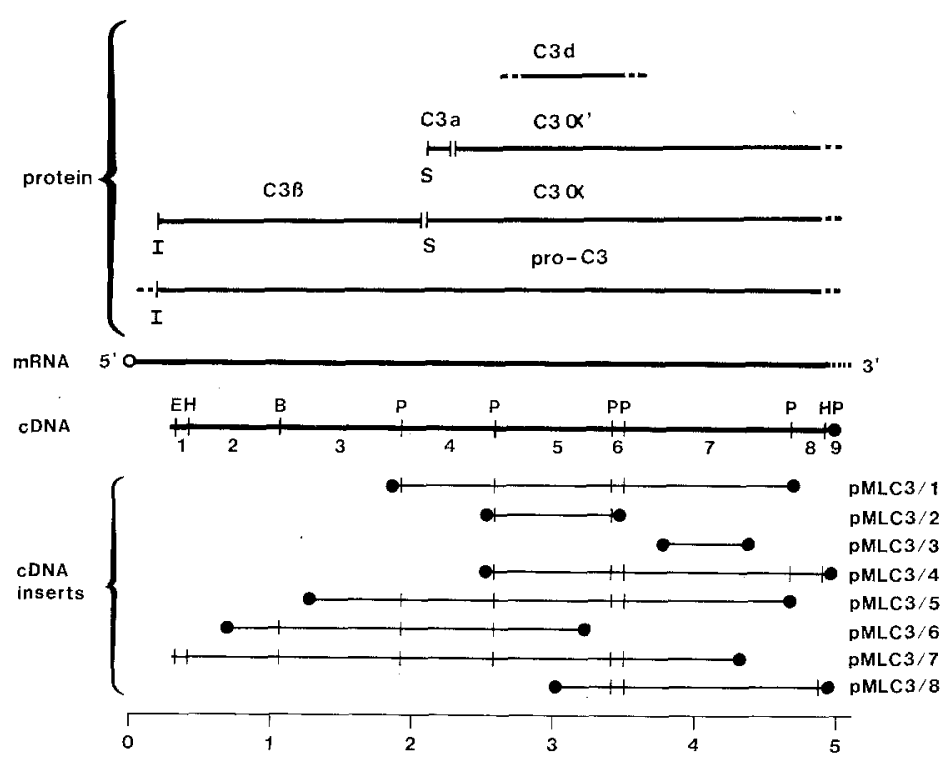

Fig. 1. (Lower) Restriction map of the cDNA inserts contained in clones pMLC3/1-8 and their location with respect to C3 mRNA. B, BamHI; EcoRI; H, HindIII; P, PstI. ——, cDNA inserts, where end circles symbolize PstI sites generated by the cloning procedure. The scale for the bottom line is in kilobase pairs (kb). (Upper) Position of the principal subunits and peptide fragments contained in the proC3 molecule, with respect to the $\mathrm{C} 3 \mathrm{mRNA}$. I, isoleucine residue at the $\mathrm{NH}_{2}$-terminus of proC3 and mature C3 $\beta$. Dots preceding I indicate the amino-terminal extension peptide in the initial translation product. S, serine residue at the $\mathrm{NH}_{2}$-terminus of $\mathrm{C} 3 \alpha$ and C3a. (Reproduced with permission, Ref. 31)

$\mathrm{NH}_{2}$-end of the mouse $\mathrm{C} 3 \beta$ subunit. The first few amino acid residues of the mature mouse $\mathrm{C} 3 \beta$ subunit, obtained from this comparison would be Ile-Pro-Met-Tyr-Ser (Fig. 2). Thus, the order of the subunits in the precursor polypeptide proC3 was deduced to be: $\mathrm{NH}_{2}-\beta-\alpha-\mathrm{COOH}$, in agreement with the earlier conclusion of Goldberger et al. [42]. These investigators immunoprecipitated intracellular proC3 and extracellular mature $\mathrm{C} 3$ from radiolabeled tissue cultures and compared the $\mathrm{NH}_{2}$-termini of the precursor and of the mature subunits by radioamino acid sequencing to establish that the $\beta$ subunit is located in the amino terminal portion of proC3. This conclusion was further supported by the identification of sequences encoding $\mathrm{C} 3 \mathrm{a}$ (the anaphylatoxin peptide) and the $\mathrm{C} 3 \alpha$ subunit at the expected positions in the central portion of the mRNA [31]. The cDNA sequences from the $5^{\prime}$ terminal mRNA region further indicated that the initial translation product from $\mathrm{C} 3 \mathrm{mRNA}$ does not start with the $\mathrm{NH}_{2}$-terminal Ile-residue of the mature $\beta$ subunit, but that it must contain an amino terminal extension peptide. From genomic DNA sequences, later results showed that the initial translation product must begin with a leader- or signal-peptide [111] (see below and Fig. 6).

The amino acid sequences of the mouse C3a anaphylatoxin peptide and of adjacent regions in the precursor proC3 molecule are given in Fig. 3. The $\mathrm{COOH}$ terminus of the mouse $C 3 \beta$ chain has not been located precisely in this region because the amino acid sequence of mouse $\mathrm{C} 3$ is unknown. However, the $\mathrm{COOH}$ - 


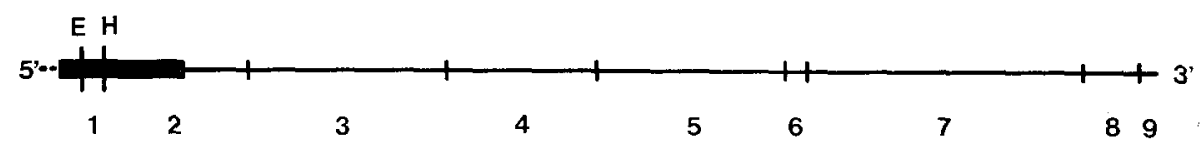

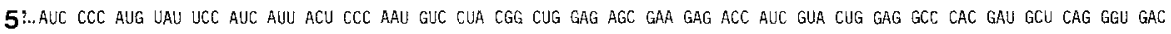

$\begin{array}{lllllllllllllllllllllllllllllllllllllllll} & P & M & Y & S & I & I & T & P & N & V & L & R & L & E & S & E & E & T & I & Y & L & G & A & H & 0 & A & Q & G & 0\end{array}$

AUC CCA GUC ACA GUC ACU GUG CAA GAC UUC CUA AAG AGG CAA GUG CUG ACC AGU GAG AAG ACA GUG UUG ACA GGA GCC AGU GGA CAU CUG AGA

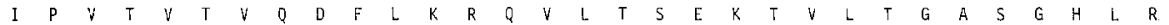
AGC GUC UCC AUC AAG AUU CCA GCC AGU AAG GAA UUC AAC UCA GAU AAG GAG GGG CAC AAG UAC GUG ACA GUG GUG GCA AAC UUC GGG GAA ACG

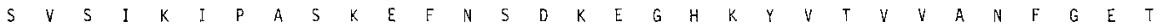
H

GUG GUG GAG AAA GCA GUG AUG GUA AGC UUC CAG AGU GGG UAC CUC UUC AUC CAG ACA GAC CAG ACC AUC UAC ACC CCC GGC UCC ACU GUC UUA

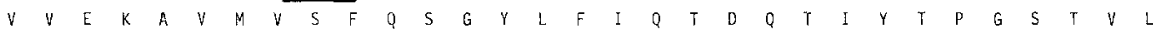

UAU CGG AUC UUC ACU GUG GAC AAC AAC CUA CUG CCC GUG GGC AAG ACA GUC GUC AUC CUC AUU GAG ACC CCC GAU GGC AUU CCU GUC AAG AGA $\begin{array}{lllllllllllllllllllllllllllllllll}Y & R & I & F & T & V & D & N & N & L & L & P & V & G & K & T & V & V & I & L & I & E & T & P & G & G & 1 & P & V & K & R\end{array}$ GAC AUU CUG UCU UCC AAC AAC. CAA CAC GGC AUC UUG CCU UUG UCU UGG AAC AUU CCU GAA CLG GUC. AAC AUG GGG CAG UGG AAG AUC CGA GCC

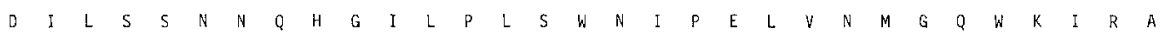
UUU UAC GAA CAU GCG CCG-AAG CAG AUC UUC UCC GCA GAG UUU GAG GUG AAG GAA UAC GUG CUG GCC AGU UIU GAG GUC CGG GUG GAG CCC AC.

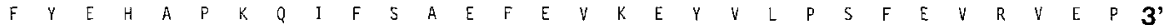

Fig. 2. Amino acid and corresponding nucleotide sequence of the $\mathrm{NH}_{2}$-terminus of mouse $\mathrm{C} 3 \beta$. (Top) The thickened portion in fragments 1 and 2 and an area preceding fragment 1 were sequenced. The sequence of this preceding region was determined from primer-extended cDNA. $\mathrm{E}=\mathrm{EcoRI} ; \mathrm{H}=\mathrm{HindIII}$ restriction sites. (Bottom) $\mathrm{mRNA}$ and amino acid sequence (single letter code), beginning with the $\mathrm{NH}_{2}$ terminal Ile residue of the mature $\mathrm{C} 3 \beta$ subunit. $\mathrm{E}, \mathrm{H}=$ EcoR I and HindIII sites as ind icated in the top row

terminus of human C3 was established as Pro-Ala-Ala by Tack and colleagues [96]. A Pro-Ala-Ala tripeptide is also found in the mouse proC3 sequence derived from cDNA (Fig. 3). Assuming that this tripeptide is indeed the $\mathrm{COOH}$-terminus of mouse $\mathrm{C} 3 \beta$ and that the $\mathrm{NH}_{2}$-terminal residues of mouse C3a are Ser-Val-Gln, the precursor molecule contains an additional four arginine residues between these regions that are not part of the mature protein. These residues must be removed during the process in which the precursor matures into the two-chain molecule.

One can further deduce from the cDNA sequence that mouse $\mathrm{C} 3 \mathrm{a}$ is a 78 amino acid residue peptide of the same length as rat $\mathrm{C} 3 \mathrm{a}$. In contrast, human and porcine $\mathrm{C} 3 \mathrm{a}$ are 77 residues long $[25,47,49]$. The sequence shows that mouse C3a shares $72 / 78$ residues $(92 \%$ homology) with rat $\mathrm{C} 3 \mathrm{a}$, and $52 / 77$ and $50 / 77$ residues with human and porcine $\mathrm{C} 3 \mathrm{a}$, respectively $[25,47,49]$. Furthermore, the cDNA sequence indicates that the cleavage of $\mathrm{C} 3$ by the $\mathrm{C} 3$ convertases occurs by hydrolysis of a single peptide bond. All of the amino acid residues contained in the $\mathrm{C} 3 \alpha$-chain's cleavage site are retained either in the $\mathrm{COOH}$-end of $\mathrm{C} 3 \mathrm{a}$ or in the $\mathrm{NH}_{2}$-end of the $\mathrm{C} 3 \alpha^{\prime}$-chain, confirming earlier reports $[48,96]$.

The amino acid sequence of the thioester bond region [95] was derived from the cDNA sequence (Fig. 4). By comparison with published data on the protein sequence, this region is evidently highly conserved between mouse and human C3 (35/41 amino acid residues identical). In particular, all ten amino acid residues common to the thioester regions of human $\mathrm{C} 3, \mathrm{C} 4$, and $\alpha_{2}$-macroglobulin, and which are considered essential for the functioning of this region $[17,45,95,99]$, also occur in mouse C3. These residues are surrounded by a solid line in Fig. 4. 

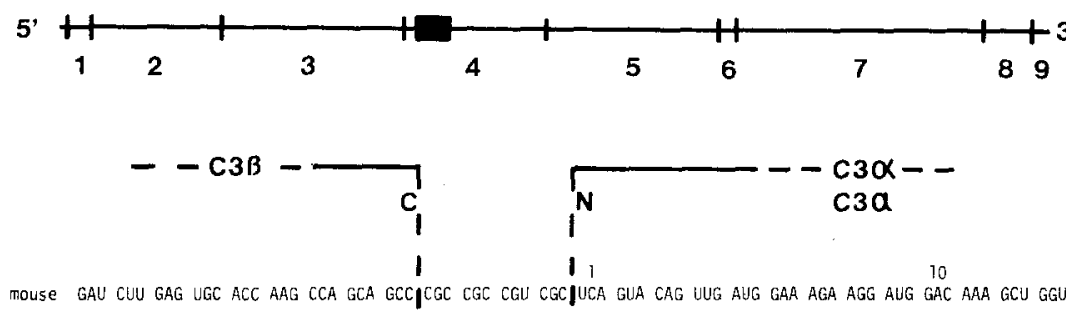

mouse GAU CUU GAG UGC ACC AAG CCA GCA GCCJCGC CGC CGU CGCJUCA GUA CAG UUG AUG GAA AGA AGG AUG GAC AMA GCU GGU

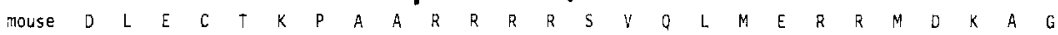
rat $\quad S \quad V \quad Q \quad L \quad M \quad E \quad R \quad R \quad M \quad D \quad K \quad A \quad G$ human $P$ A $A$ A $\quad S \quad V \quad Q \quad L \quad T \quad E \quad K \quad R \quad M \quad N \quad K \quad V \quad G$ porc $\quad S \quad V \quad Q \quad L \quad M \quad E \quad K \quad R \quad M \quad N \quad K \quad L \quad G$

mouse CAG UAC ACU GAC AAG GGU CUU CGG AAG UGU UGU GAG GAU GGU AUG CGG GAU AUC CCU RUG AGA UAC AGC UGC CAG CGC

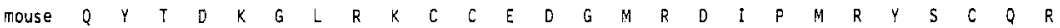

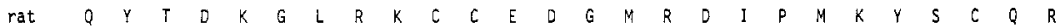

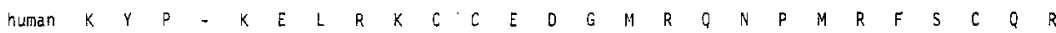

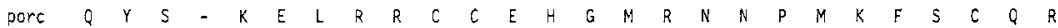
mouse CGG GCA CGC CUC AUC ACC CAG GGC GAG AAC UGC AUA AAG GCC LUC AUA GAC UGC UGC AAC CAC ALC ACC AAG CUG CGU

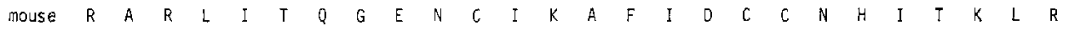

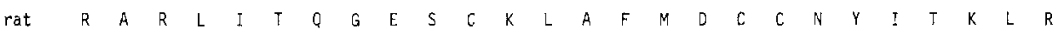

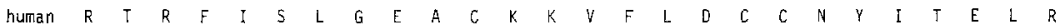

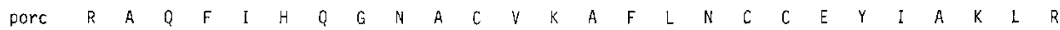

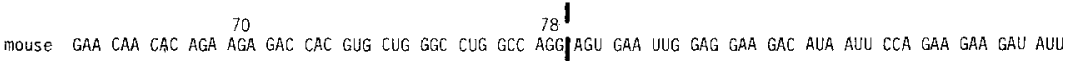

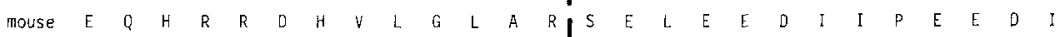
rat $E$ Q $\quad H \quad R \quad R \quad D \quad H \quad V \quad L \quad G \quad L \quad A \quad R$

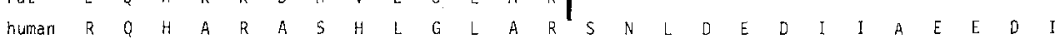

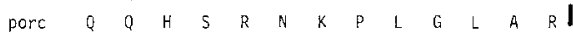

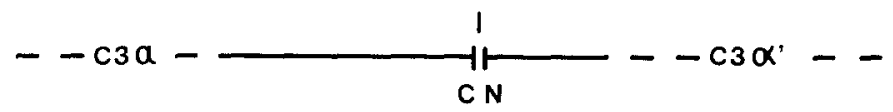

Fig. 3. Comparison of the amino acid sequences of $\mathrm{C} 3 \mathrm{a}$ and its flanking regions. (Top) $\boldsymbol{\square}$, Portion of fragment 4 whose sequence was determined. The positions of the $\mathrm{COOH}$-terminus (C) of the $\mathrm{C} 3 \beta$ subunit and the $\mathrm{NH}_{2}$-terminus ( $\mathrm{N}$ ) of the $\mathrm{C} 3 \alpha$ subunit and the $\mathrm{C} 3 \mathrm{a}$ fragment are shown. (Middle) Amino acid sequences. The mouse mRNA sequence was derived from cDNA sequence. Rat, human, and porcine amino acid sequence were taken from Jacobs et al. [49], Hugli [47], and Corbin and Hugli [25], respectively. (Bottom) Positions of the COOH-terminus (C) of C3a and the $\mathrm{NH}_{2}$-terminus (N) of C3 $\alpha^{\prime}$. (Reproduced with permission, Ref. 31)

Surprisingly, however, the second glutamyl residue, which is involved in formation of the thioester bond (residue 26 in Fig. 4), is coded as a glutamine. This finding must be considered in formulating mechanisms for the biosynthesis of this important bond $[31,38,51]$.

The $\mathrm{COOH}$-terminus of the mouse $\mathrm{C} 3$ protein has not yet been positioned on the cDNA map. One of the cDNA clones (pML C3/4, Fig. 1) contains a sequence that probably represents the 3'-end of the C3 mRNA. This clone contains a stretch of seven adenosine residues preceding the homopolymeric tail that links the insert to the plasmid vector and 16 nucleotides upstream a polyadenylation signal AAUAAA [80], which follows translational termination codons in all three reading frames. Thus, it was concluded that this region represents the $3^{\prime}$ end of C 3 mRNA. However, 


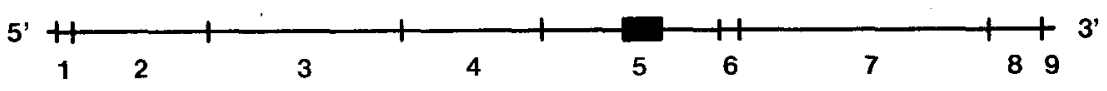

mouse GUU CMA AUG GCU GMA GAU GCU GUG GAC GGG GAG CGG CUG AAA CAC CUG AUC GUG ACC CCC

\begin{tabular}{|c|c|c|c|c|c|c|c|c|c|c|c|c|c|c|c|c|c|c|c|c|}
\hline mouse & $\mathrm{V}$ & $Q$ & $\mathrm{M}$ & $\Lambda$ & $\mathrm{E}$ & D & $A$ & $\mathrm{v}$ & $\mathrm{D}$ & $G$ & $E$ & $\mathrm{R}$ & $\mathrm{L}$ & $\mathrm{K}$ & $\mathrm{H}$ & $\mathrm{L}$ & I & $\mathrm{V}$ & $\mathrm{T}$ & $P$ \\
\hline human & v & $\mathrm{Q}$ & $M$ & $T$ & $E$ & $\mathrm{D}$ & $A$ & V & $D$ & $A$ & $E$ & $\mathrm{R}$ & $\mathrm{L}$ & $\mathrm{k}$ & $\mathrm{H}$ & $\mathrm{L}$ & I & V & $\mathrm{T}$ & P \\
\hline
\end{tabular}

mouse GCC GGC UGU GGG GAA CAG AAC AUG AUU GGC AUG ACA CCA ACA GUC AUU GCG GUA CAC UAC CUG a

\begin{tabular}{|c|c|c|c|c|c|c|c|c|c|c|c|c|c|c|c|c|c|c|c|c|c|}
\hline mouse & A & G & C & G & E & $Q$ & $\mathrm{~N}$ & $M$ & $I$ & G & $M$ & $T$ & $\mathrm{P}$ & $\mathrm{T}$ & V & $I$ & A & $\mathrm{V}$ & $\mathrm{H}$ & $\mathrm{Y}$ & L \\
\hline human & $S$ & G & C & $G$ & $\mathrm{E}$ & Z & $N$ & $M$ & $I$ & G & $M$ & $\mathrm{~T}$ & $\mathrm{p}$ & $\mathrm{T}$ & $V$ & I & $A$ & $\mathrm{~V}$ & $S$ & $Y$ & L \\
\hline
\end{tabular}

Fig. 4 Comparison of the amino acid sequences encompassing the internal thioester site from murine (predicted from the nucleotide sequence) and human [99] C3d. (Upper) $\boldsymbol{m}$, Portion of fragment 5 whose sequence was determined. (Lower) Numbering of amino acid residues in the C3d fragment is from Thomas et al. [99]. The boxes indicate conserved amino acid residues that are identical in human C3d, C4d, and $\alpha 2$-macroglobulin [17, 45] (Reproduced with permission, Ref. 31)

the possibility that this is only an internal adenosine-rich stretch in the $3^{\prime}$ nontranslated region of the mRNA and that the real $3^{\prime}$ end of the mRNA is located further downstream is not excluded. The $\mathrm{COOH}$-end of the protein must be coded by this region or by sequences located further upstream. No amino acid sequences are known for mouse $\mathrm{C} 3$; therefore, only human $\mathrm{C} 3 \alpha$ can be used for comparison. The COOH-terminal amino acids of the human $\mathrm{C} 3 \alpha$ chain have been determined to be (Ala, Val)-Gly-Ser [96]. However, this tripeptide sequence has one uncertainty and neither matches nor resembles the mouse protein sequences derived from the cDNA sequence preceding the stop codons in any of the three reading frames. This could mean that murine and human $\mathrm{C} 3$ have very different $\mathrm{COOH}$-termini. Alternatively, the sequence reported for the $\mathrm{COOH}$-end of the human $\mathrm{C} 3 \alpha$ chain may not correspond to the COOH-end of the initial translation product. The published tripeptide sequence could represent the $\mathrm{COOH}$-end of a processed version of $\mathrm{C} 3 \alpha$ generated from the initial translation product by removal of carboxyterminal amino acid residues. Carboxyterminal processing of both the murine and human $\mathrm{C} 4 \alpha$-chains has recently been reported $[20,50]$ and may also occur for $\mathrm{C} 3$.

3) Structure and Characterization of the Mouse C3 Gene. A gene library was constructed with liver DNA from adult mice of the inbred strain A/Jax by using the phage vector 21059 . DNA was partially digested with the restriction endonuclease $\mathrm{MboI}$, and DNA fragments of 13-23 kilo basepairs $(\mathrm{kb})$ in length were recovered by preparative electrophoresis in agarose gels. The fragments were ligated into the Bam HI restriction sites of the phage vector, and phage particles were reconstituted by in vitro packaging with viral protein capsids. A library representing the entire Amouse genome was obtained and screened by plaque hybridization with radiolabeled, cloned C3 cDNA probes. Four genomic clones were isolated and characte- 
rized. Two of them, $\lambda \mathrm{MC} 3 / \mathrm{KW} 4(\mathrm{KW} 4)$ and $\lambda \mathrm{Mc} 3 / \mathrm{KW} 7(\mathrm{KW} 7)$, contained one entire copy of the mouse $\mathrm{C} 3$ gene together with approximately $1.2 \mathrm{~kb}$ of $5^{\prime}$-and $7 \mathrm{~kb}$ of $3^{\prime}$-flanking sequences [111] (Fig. 5). The gene is approximately $24 \mathrm{~kb}$ long, and the $5^{\prime}$ and $3^{\prime}$ ends were mapped precisely by comparative DNA sequence analysis of cDNA and genomic DNA. For this purpose, cDNA extending to the $5^{\prime}$ end of the mRNA was generated in primer-extension experiments by using cloned cDNA fragments as primers [111]. In this manner, the sequence coding for the $5^{\prime}$ end of the mRNA (cap) was located on the genomic DNA with a precision of \pm 2 nucleotides (position indicated by arrow in Fig. 6). A 232 bp Hind III-Bam HI genomic DNA fragment containing the cap site was sequenced, and the hexanucleotide TATAAA (termed a TATA-box, underlined in Fig. 6) was found 28 nucleotides upstream from the cap site. This hexanucleotide is a typical sequence in RNA polymerase II promoter regions of eucaryotic genes $[26,41]$. The ATG translation initiation triplet is located 56 nucleotides downstream from the cap site. The following $72 \mathrm{bp}$ contain coding information for a signal- or leader-peptide $[13,62]$ of typical amino acid sequence and composition [10] (Fig. 6). After the triplets coding for the 24 amino acids of the signal-peptide, the genomic DNA encodes the $\mathrm{NH}_{2}$-terminus of the mature $\mathrm{C} 3 \beta$ chain (Ile-Pro-Met). The signal hypothesis states that secreted glycoproteins are synthesized as primary translation products containing a signalpeptide, most often located at their $\mathrm{NH}_{2}$-end. Signal peptides are generally removed co-translationally by specific proteolytic cleavage [13]. C3 is a secreted glycoprotein, and from the gene sequence, it appears that the primary translation product carries a signal peptide. This signal-peptide possesses the following typical properties [10]: (a) its length (24 amino acids) falls into the normal range for such peptides, (b) it consists exclusively of uncharged amino acids, (c) its last residue is a
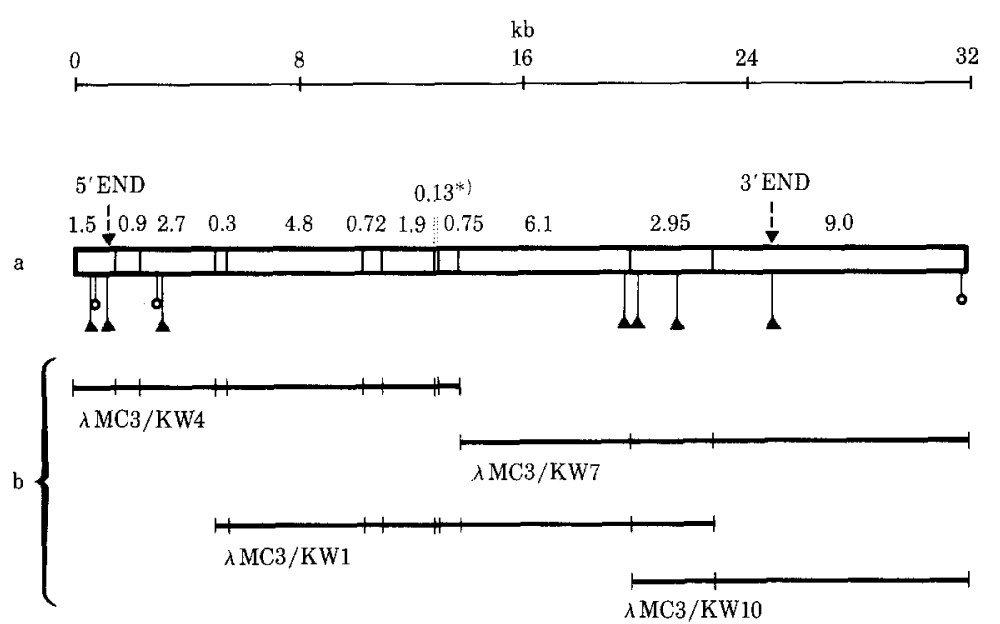

Fig. 5. a Restriction map of the $\mathrm{C} 3$ gene. BamHI restriction fragments are shown by open boxes (the 0.13 $\mathrm{kb}$ fragment marked by an asterisk is possibly located towards the $3^{\prime}$ side of the neighboring $0.75 \mathrm{~kb}$ fragment). O, EcoRI sites; $\boldsymbol{\Delta}$, HindIII sites, $\downarrow$, Positions of the T-A-T-A-A-A box ( $5^{\prime}$ end of the gene), and of the poly (A) addition site (3' end of the gene). $\mathbf{b}$ Restriction map of genomic DNA inserts carried by four different C3 clones. Vertical bars indicate BamHI restriction sites. (Reproduced with permission, Ref. 111) 


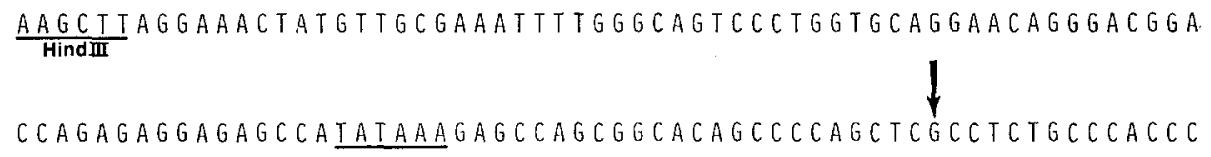

Met Gly Pro Ala Ser Gly

CTGCCCCTTACCCCTICATTCCTTCCACCTTTTTCCTTCACTATGGGACCAGCTTCAGGG

Ser GiN Leu leu val leu leu leu leu leu Ala ser ser pro leu Ala leu gly lle Pro

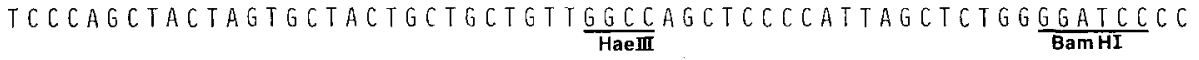

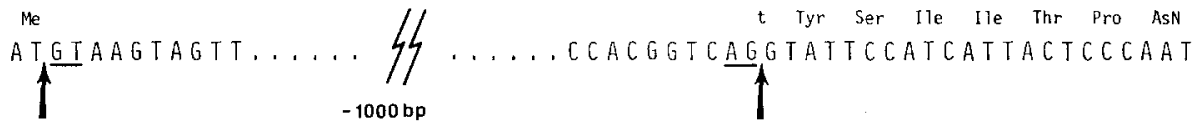

$232 \mathrm{bp}$

$-900 \mathrm{bp}$

$-660 \mathrm{bp}$

$86 \mathrm{bp}$

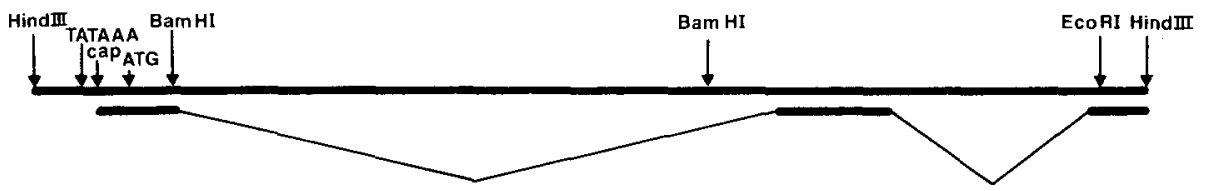

Fig. 6. (Upper) Nucleotide sequence of the 232 bp HindIII-BamHI fragment, which contains the $5^{\prime}$ end of the gene and partial sequence of the $3^{\prime}$-neighboring $900 \mathrm{bp}$ and $2700 \mathrm{bp}$ BamHI fragments. The T-A-T-AA-A hexanucleotide, the ATG translation initiation codon, and the first and last two nucleotides of the first intron are underlined. $\uparrow$, the exact exon/intron boundaries; $\downarrow$, the probable first nucleotide of the C3 mRNA. The $\mathrm{NH}_{2}$-terminal amino acid residues, comprising the signal peptide and the first amino acids of the $\mathrm{C} 3 \beta$ subunit, are written above the triplet codons from which they are deduced. (Lower) Block structure of the first, second, and the beginning of the third exon. The heavy line in the bottom row represents exons. The thin inclined line symbolizes intron sequences that are absent from the mRNA and the cDNA. (Reproduced with permission, Ref. 111)

glycine, and the transition dipeptide (Gly-Ile) is a preferred substrate for the signalpeptidases known so far, (d) it contains a proline within its last six residues, and (e) its central portion consists of eight hydrophobic residues in an uninterrupted sequence. One additional observation supports the hypothesis that the sequence described above is a signal-peptide. As evident from the genomic DNA sequence, it is coded by a separative first exon of the gene [111] (Fig. 6). The sequences coding for the signalpeptides of other genes (mouse immunoglobulin light chains, [102] histocompatibility antigens, $[55,56,92])$ are often contained in a separate first exon of the gene.

From these data, several general properties of the mouse $\mathrm{C} 3$ gene can be deduced. It is $24 \mathrm{~kb}$ long, four to five times longer than the mRNA coding sequences. Therefore, the ratio of noncoding to coding sequences is approximately $4: 1$. This number falls into the range found for other eucaryotic genes transcribed by RNA polymerase II. The gene must contain intervening sequences (introns) and sequences retrieved in the mature mRNA (exons), but their exact numbers, sizes, and locations have not yet been determined except for the first and second exons and introns [111]. The promotor region contains the principal sequence known to be 
conserved for many polymerase II genes, the TATA-box. The C3-TATA-box perfectly agrees with the consensus sequence in all six nucleotide positions $[26,41]$. The distances from the TATA-box to the cap-site and from the cap-site to the translation initiation site fall into the usual range. Obviously, the promoter region will have to be studied in much greater detail to define other sequence elements relevant to the initiation of transcription by polymerase II and its regulation by tissue-specific and inflammatory signals.

With regard to expression control in general and to tissue-specific expression in particular, it is important to know the number of $\mathrm{C} 3$ genes present in one (haploid) set of mouse chromosomes. If the genome contains a family of several C3 genes, tissue-specific expression could be achieved through selective expression of one different member in each different producer tissue. Alternatively, if only one copy is present per haploid genome, then the same gene must be expressed in all the different producer tissues. If several gene copies are present in the genome, increased C3 synthesis during acute inflammation could be achieved through the "switching on" of additional, normally silent gene copies, whereas the rate of expression from the constitutively expressed gene could remain constant. Alternatively, if only one copy of the gene is present, then increased synthesis during inflammation most likely would require an increased rate of expression from this single gene. To investigate whether the mouse genome contains one or several variants of the C3 gene, mouse liver DNA was digested with restriction enzymes and subjected to Southern blot analysis in parallel with similarly digested DNA from a mixture of the recombinant phages KW4 and KW7 (Fig. 7). A mixture of cloned cDNA fragments, including all of the C3 mRNA sequences obtained as cloned cDNA until now, plus the $232 \mathrm{bp}$ genomic DNA fragment containing the $5^{\prime}$ end of the gene were radiolabeled and used as probes. All of the Bam HI restriction fragments detected in the digest of genomic DNA also were found in one of the two phages (Fig. 7). Similar results were obtained with the restriction enzymes ECoRI and Hind III (unpublished data). Therefore, the mouse genome carries only one type of $\mathrm{C} 3$ gene recognizable by this analysis. If more than one copy of the $\mathrm{C} 3$ gene was present, then all must give rise to the same Bam HI, ECoRI, and Hind III restriction patterns. This analysis did not exclude the possibility that several copies of the $\mathrm{C} 3$ gene exist per haploid set of chromosomes, however, if several copies do exist, they must all have strictly conserved patterns of restriction enzyme cleavage. In view of the known rapid evolution of intron sequences, this is considered improbable. To the authors' knowledge, no gene of comparable length $(24 \mathrm{~kb})$ with two or more copies per genome and with strictly conserved cleavage patterns for three different restriction enzymes has been reported in the literature. Therefore, precise titration of the gene copy number using quantitative Southern blot or liquid hybridization experiments is needed and must include calibration by internal standards. From the data available, the mouse genome contains only one copy of the C3 gene and no pseudogenes, and this is the copy represented by the two recombinant phages $\lambda \mathrm{MC} 3 / \mathrm{KW} 4$ and $\lambda \mathrm{MC} 3 / \mathrm{KW} 7$ [111].

4) C3 Allotypes and Chromosomal Location of the C3 Gene. Electrophoretic variants of the mouse C3 protein were first discovered by Penalva da Silva and colleagues [77] using high voltage electrophoresis of fresh mouse serum in agarose gels. This 
Fig. 7. Demonstration of a single type of $\mathrm{C} 3$ gene by Southern blot analysis. Equal amounts of DNA from phages KW4 and KW7, see Fig. 5, were mixed and digested with the restriction enzyme BamHI. In parallel, liver DNA from strain $\mathrm{A} / \mathrm{J}$ ax mice was digested with BamHI. The resulting fragments were separated by electrophoresis in a $0.9 \%$ agarose gel, denatured, and transferred onto nitrocellulose filters (Southern blot). The filter was hybridized with a mixture of nicktranslated DNA from cDNA plasmids, which represent 4600 of the 5100 nucleotides of the C3 mRNA sequence, and with the nicktranslated gel eluted 232 bp HindIII-BamHI fragment from phage KW4, which contains the $5^{\prime}$ end of the mouse C3 gene (see Fig. 6). Lanes a, b: $1 \mathrm{ng}$ and $0.5 \mathrm{ng}$, respectively, of the mixture of phage DNAs KW4 and $\mathrm{KW}$. Lanes c, d: $15 \mu \mathrm{g}$ and $10 \mu \mathrm{g}$, respectively, of mouse liver DNA. Fragment sizes are given in kilobases (kb) as determined from size markers electrophoresed in the same gel. The $23.1 \mathrm{~kb}$ mark on the left indicates traces of annealed phage arms containing partially digested insert fragments

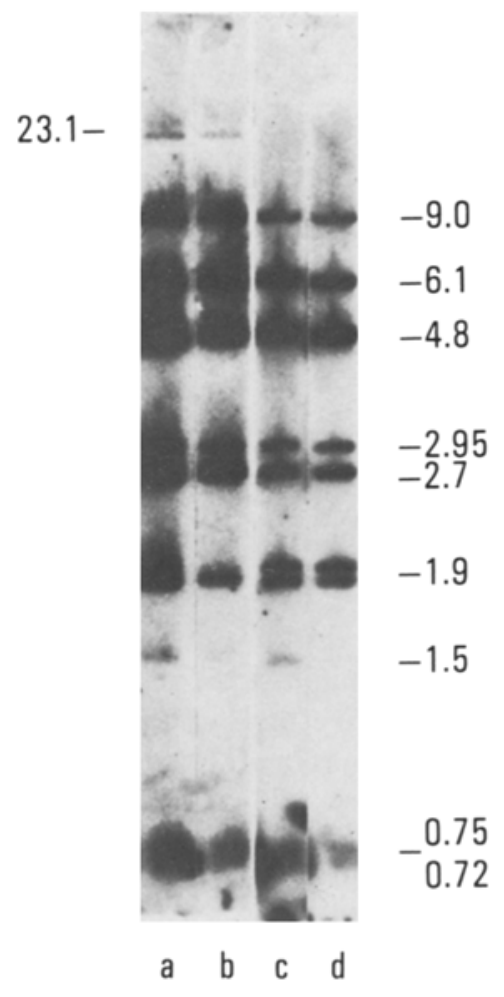

technique had been used before $[2,4,84]$ for the analysis of human $\mathrm{C} 3$ variants. Two murine variants were found, a fast migrating $(F)$ protein and a slow one (S), similar to the two common forms found for human C3 [112]. Most inbred mouse strains were found to be homozygous for the $\mathrm{S}$ allele and only $4 / 46$ strains had the alternative $F$ allele. Penbred Swiss-Webster animals belonged to one of the three phenotypes $\mathrm{S}, \mathrm{F}$, or $\mathrm{SF}$. The genes responsible for this variation were codominantly expressed and segregated as alleles of a single Mendelian locus. Segregation studies were performed after crossing $\mathrm{S}$ and $\mathrm{F}$ strains of known haplotypes in the major histocompatibility complex (MHC), and both the $\mathrm{C} 3$ and $\mathrm{MHC}$ markers were analyzed in the progeny. $\mathrm{C} 3$ and the MHC markers segregated together with a recombination frequence of $12 \%$. The conclusion was that the $\mathrm{C} 3$ gene is linked to the MHC on mouse chromosome 17 but must be located outside the MHC, because the recombination distance between the $\mathrm{MHC}$ and $\mathrm{C} 3$ is 12 centimorgans (cM) whereas the MHC is less than $1.5 \mathrm{cM}$ long. Natsuume-Sakai and coworkers [69] used different techniques (isoelectric focusing and immunofixation) and discovered two isoelectric variants of mouse C3. From the strain distribution of these variants and from breeding experiments, they concluded that the isoelectric variation of mouse $\mathrm{C} 3$ is inherited as an autosomal, codominant trait controlled by a single locus, designated C3-1. They observed linkage between C3-1 and the S region of the $\mathrm{MHC}$ and between $\mathrm{C} 3-1$ and the kidney catalase locus $\mathrm{Ce}-2$ on chromosome 17 . The distances reported were: $\mathrm{C} 3-1 / \mathrm{Ce}-2=23 \mathrm{cM} ; \mathrm{C} 3-1 / \mathrm{S}=11 \mathrm{cM}$, in close agreement 
with the conclusion of Penalva da Silva et al. [77]. The alleles controlling the isoelectric variants were called $\mathrm{C} 3-1^{\mathrm{a}}$ and $\mathrm{C} 3-1^{\mathrm{b}}$, but the relationship between these and the electrophoretic variants [77] was not established. Subsequently, the Japanese group raised a mouse alloantiserum directed against a determinant $A$ carried by the product of the C3-1 ${ }^{a}$ allele. With the help of this serum they detected a third allele, C3-1 $1^{\mathrm{c}}$, at the $\mathrm{C} 3-1$ locus. The corresponding protein has a similar isoelectric point as the $\mathrm{C} 3-1^{\mathrm{a}}$ product but lacks the A determinant [70]. Later the same authors generated alloantisera capable of recognizing exclusively determinants $\mathrm{B}$ and $\mathrm{C}$ on the products of the $\mathrm{C} 3-1^{\mathrm{b}}$ and $\mathrm{C} 3-1^{\mathrm{c}}$ alleles $[71,73]$.

In subsequent studies the Japanese authors used both the isoelectric focusing technique and these alloantisera for phenotyping C3 variants. They performed a three-factor-cross analysis using "tufted" (tf), a mutant"gene locus $9 \mathrm{cM}$ away from the centromere of chromosome 17 . To determine definitely the chromosomal location of C3-1, they phenotyped backcross progeny for the expression of tf and C3-1, and established that a distance of $24 \mathrm{cM}$ separated these two markers [72]. Since the distance between $\mathrm{tf}$ and the $\mathrm{MHC}$ was known to be about $7 \mathrm{cM}$, the chromosomal arrangement was concluded to be: centromere-tf-MHC-C3. Rubinstein et al. [86] confirmed this arrangement, using glyoxalase (glo) instead of tf as a third marker in a three-factor-cross. Glo was located at $17 \mathrm{cM}$ on the centromeric side of the MHC and C3-1 on the distal side at a distance of $11 \mathrm{cM}$.

The alloantisera were finally used to describe the molecular differences between the protein products of the three C3-1 alleles [73]. After the three proteins were purified to homogeneity, they retained the same isoelectric and immunologic properties as in whole serum. Thus, the allotypic differences were attributed to differences in the primary structures of the corresponding gene products. By tryptic digestion, the allotypic determinants $A$ and $B$ were further located in the $C 3 c$ fragment. All three proteins had very similar subunit sizes and compositions, distributions, and content of neutral sugars and sensitivity to tryptic digestion. The $\beta$ subunit of all three murine proteins were shorter than the human $\mathrm{C} 3 \beta$ subunit by a molecular weight difference of 9000 . Whereas both the human $\alpha$ and $\beta$ subunit are known to be glycosylated, only the murine $C 3 \alpha$ subunit was found to be glycosylated; the $\beta$ subunit was not, confirming earlier reports [37]. But, glycosylation differences alone could not account for the size difference between the murine and human $\beta$ subunit; therefore, a difference of the amino acid chain length is probably involved. In this context, it may be noted that Carroll and Capra [19] have observed significant phylogenetic variation in the size of the $C 3 \beta$ subunit, but very little variation in the $\mathrm{C} 3 \alpha$ subunit.

\section{B. The Human C3 Gene}

1) Preparation of Cloned Human C3 DNA Probes. The degree of relatedness between nucleotide sequences of mouse and human $\mathrm{C} 3$ was qualitatively evaluated in a Southern blot hybridization experiment (Fig. 8). The patterns of restriction enzyme cleavage were identical for liver DNA from two inbred mouse strains, A/Jax (s/s) and GR (f/f), homozygous for the two major electrophoretic variants $S$ and $F$ of the mouse $C 3$ protein [77]. In contrast, the cleavage patterns of human peripheral blood cell DNA generated with three restriction enzymes differed greatly in 


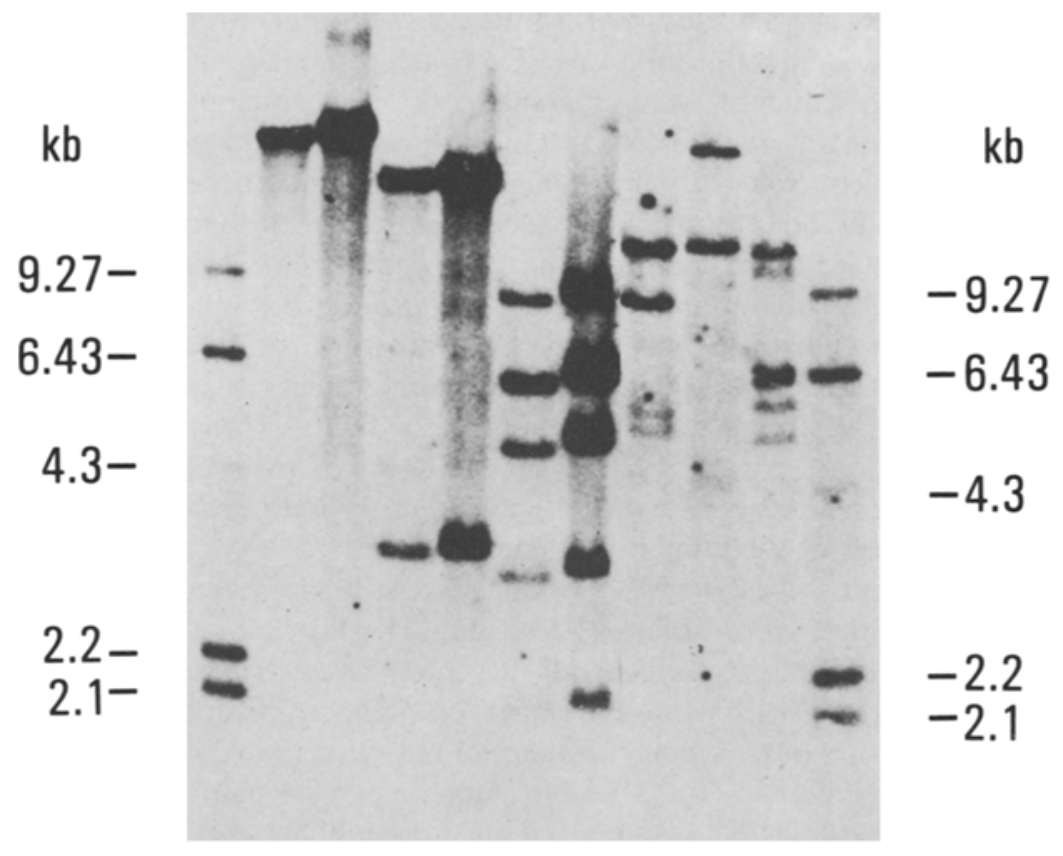

\section{$\begin{array}{lllllllllll}M & 1 & 2 & 3 & 4 & 5 & 6 & 7 & 8 & 9 & M\end{array}$}

Fig. 8. Homology between murine and human C3 sequences. Murine liver DNA and human peripheral blood cell DNA were separately digested with three different restrictions endonucleases, EcoRI (E), HindIII (H), and BamHI(B). The fragments were separated by electrophoresis in agarose gels and subsequently transferred to a nitrocellulose filter (Southern blot). The filters were hybridized with a mixture of two mouse C3 cDNA plasmids carrying inserts that represent 4600 of the 5100 nucleotides of the C3 mRNA (plasmids pML C3-4 and pML C3-7 in Fig. 1). Molecular weight size markers (first and last track, M) are lambda phage DNA, digested with the restriction enzyme $\mathrm{H}$ and endlabeled with polynucleotide kinase and ${ }^{32}$ P-gamma ATP. Fragment sizes are given in kilobases (kb). Tracks 1,2 : DNA from A/Jax and GR-mice (C3-s/s and C3-f/f genotype, respectively [77]) digested with E; Tracks 3, 4: DNA from A/Jax and GR-mice digested with $\mathrm{H}$; Tracks 5, 6: DNA from A/Jax and GR-mice digested with $B$; Tracks 7-9: Human DNA digested with $E, H$, and $B$, respectively

fragment sizes from the corresponding patterns of mouse DNA. Therefore, sequence diversion is clearly detectable between the two species. Nevertheless, a substantial amount of sequence homology persists because mouse cDNA probes hybridize efficiently with human sequences, and the hybrids remain stable under conditions of moderate stringency $\left[1 \times \mathrm{SSC}\right.$ (standard sodium citrate buffer), $65^{\circ} \mathrm{C}, 1 \mathrm{~h}$ )]. This observation suggests the usefulness of mouse $\mathrm{C} 3 \mathrm{cDNA}$ as a probe to isolate human $\mathrm{C} 3$ genomic DNA clones. In this manner one human $\mathrm{C} 3$ genomic clone, $\lambda \mathrm{HuC} 3 \mathrm{RI}$ No. 5, was isolated from a gene library of partial EcoRI fragments of human DNA in a $\lambda$ replacement vector prepared by Fritsch and coworkers [39]. This clone contained a $12 \mathrm{~kb}$ EcoRI fragment of the human C3 gene and a flanking $5.2 \mathrm{~kb}$ fragment. The exon-intron map of the insert has not been determined, but from hybridization with mouse $\mathrm{C} 3 \mathrm{cDNA}$ probes representing different mRNA regions, 
this area contains coding sequences for part of the C $3 \alpha$ subunit (Fey, unpublished results). To generate a specific probe for human $\mathrm{C} 3$ sequences, portions of the insert containing nonrepetitive sequences were subcloned. For this purpose purified $12 \mathrm{~kb}$ and $5.2 \mathrm{~kb}$ insert fragments were digested with several restriction enzymes, and the fragments were analyzed by Southern blot analysis with total nick-translated DNA from human peripheral blood cells used as a probe. Insert fragments giving rise to a hybridization signal under these conditions contain repetitive sequences. In this experiment, a $1.39 \mathrm{~kb}$ Pst I subfragment of the $12 \mathrm{~kb}$ insert fragment was found to be nonrepetitive and it was subcloned [110] in the plasmid vector pxf3, a derivative of the standard vector pBR322 [14] (a gift of Dr. D. Hanahan, Harvard University) and in M13 phage [61] (Southgate and Fey, unpublished data). Considering that inserts of the resulting clones, pxHu C3 pst 1.39 and M13 Hu C3 pst 1.39, hybridized back to $\alpha$-chain coding sequences of mouse C 3 cDNA, they must, at least in part, represent exon sequences of the human $\mathrm{C} 3$ gene.

From this experiment it was also evident that almost all subfragments of the $\lambda \mathrm{Hu}$ C3 RI No. 5 insert that are larger than $2 \mathrm{~kb}$ contain highly repetitive sequence elements. This is in agreement with the generally accepted model that human intron sequences are interspersed with short stretches of highly repetitive sequence elements (200-300 bp long) in an average distance of not more than $2 \mathrm{~kb}$ [29]. For this reason, the genomic clone $\lambda \mathrm{HuC} 3 \mathrm{RI}$ No. 5 could not be used directly for chromosomal mapping studies. The clones px HuC3 pst 1.39 and M13 HuC3 pst 1.39 are at present the best unique sequence probes available for the human $\mathrm{C} 3$ gene. When DNA preparations from nucleated peripheral blood cells and tissue culture fibroblasts from nine unrelated human donors were tested by Southern blot analysis, the $12 \mathrm{~kb}$ ECoRI fragment was found in all these samples by using the pst $1.39 \mathrm{~kb}$ probe [110]. The $12 \mathrm{~kb}$ fragment showed no polymorphism, although the donors originated from different countries (Germany and England), and can therefore be considered a diagnostic fragment for the human C3 gene.

2) Polymorphic Variants of the C3 Gene. Two electrophoretic variants of the $\mathrm{C} 3$ protein, a slow and a fast migrating form, show inheritance patterns defining them as the products of two common allelic versions (C3 S and C3 F) of the gene $[2,4,84$, 112]. In Caucasian populations these genes occur with frequencies of 0.79 and 0.20 , respectively, whereas in Blacks $\mathrm{C} 3 \mathrm{~F}$ is much less frequent and in at least one Oriental population group published, no polymorphism was detected [3]. In addition, until now 26 rare protein variants have been detected by one-dimensional electrophoresis and recognized in family studies as allelic gene products (Rittner, personal communication) and four rare variants by using two-dimensional electrophoresis (Teisberg and Olaisen, personal communication). Together the rare variants occur with a frequency of 0.01 in Caucasian populations. The twodimensional electrophoresis showed that the two common and the four rare variants studied so far all had charge differences in the $\beta$ chain in accordance with the findings of Carroll and Capra [19]. The molecular basis of the differences in electrophoretic mobility of these protein variants is unexplained. More variants of the gene will probably be discovered on the DNA level, because even gene variants that differ only in intron sequences but code for identical proteins can be detected. Initial data are available from three independent laboratories (Davies and 
colleagues, London; Roper and colleagues, Freiburg; Roses and colleagues, Durham, personal communication) demonstrating restriction enzyme fragment length polymorphisms (RFLP's) of the C3 gene that are detectable by hybridization with the pxHu C3 pst 1.39 probe. In family studies these gene variants were shown to segregate as alleles of the gene.

3) Chromosomal Location of the Human C3 Gene. The human C3 locus has been assigned to chromosome 19 [110]. Somatic cell hybrids, between human primary fibroblasts and mouse fibroblast-like cell lines, which carried a limited number of different human chromosomes were analyzed for the presence of the $\mathrm{C} 3$ gene. Two approaches were used: production of human C3 in particular hybrid cultures was detected using a monoclonal antibody with specificity for the human but not the mouse gene product; and DNA samples from particular hybrid cultures were analyzed in Southern blot hybridization experiments using the DNA probe pxHu C3 pst 1.39 to detect the presence of the characteristic human C3 $12 \mathrm{~kb}$ EcoRI fragment. Evidence of the presence of the human $\mathrm{C} 3$ gene was correlated with the known human chromosome content of the somatic cell hybrids. In the first approach, presence or absence of the human gene product correlated exclusively with the presence or absence of human chromosome 19 in 23 different somatic cell hybrids (Table 1) and in the second approach a similar exclusive correlation of the $12 \mathrm{~kb}$ EcoRI fragment with chromosome 19 was observed in eight different hybrids (Table 2).

The assignment of the $\mathrm{C} 3$ gene to chromosome 19 has allowed the assignment of an extensive linkage group to this chromosome. Linkage between C3 protein polymorphisms $[3,4,112]$ and a linkage group comprising the previously linked Lewis blood group (LE), myotonic dystrophy (DM), ABH secretor system, and the Lutheran blood group (LU) loci [44, 63, 83] was established [32]. This extended linkage study confirmed the previous findings of linkage between C3 and LE [105], and between C3 and DM [91]. The entire C3-LE-DM-SE-LU linkage group has subsequently been shown to be linked with the peptidase D locus (PEPD) [33] which had previously and independently been assigned to chromosome 19 [59].

From the Southern blot hybridization experiments using pxHu C3 pst 1.39 it was concluded that the human haploid genome probably contains only one copy of the $\mathrm{C} 3$ gene. The pst 1.39 probe detected only one ECoRI restriction fragment, the $12 \mathrm{~kb}$ fragment, in Southern blot experiments with human DNA. If the genome carried several copies of the C3 gene or closely related genes, then all of these should be located on chromosome 19 and all should give rise to an indistinguishable $12 \mathrm{~kb}$ ECoRI fragment. Multiple loci are not formally excluded by these results but were considered very improbable for the reasons discussed above with the mouse C3 gene. Southern blot experiments with DNA from peripheral blood cells and sperm cells from the same human donor further revealed no major detectable rearrangement of the gene between its germ line and somatic cell configuration (Fig. 9). The C3 gene, as far as can be detected with the presently available probes, is therefore different from immunoglobulin genes.

Most recently the chromosomal assignment has been further confirmed. Restriction fragment length polymorphisms (RFLPs) of the human C3 gene have been discovered in English, German, and American populations by Southern blot 
Table 1. Segregation of expression of human C3 in 23 somatic cell hybrid subclones

\begin{tabular}{|c|c|c|c|c|c|c|c|}
\hline \multirow{3}{*}{$\begin{array}{l}\text { Human } \\
\text { chromo- } \\
\text { some }\end{array}$} & & \multicolumn{6}{|c|}{ Expression of human $\mathrm{C} 3$} \\
\hline & & \multicolumn{2}{|c|}{ Concordant } & \multicolumn{2}{|c|}{ Discordant } & \multicolumn{2}{|l|}{ Total } \\
\hline & & ++ & -- & +- & -+ & Concordant & Discordant \\
\hline 1 & & 8 & 1 & 1 & 4 & 9 & 5 \\
\hline 2 & & 5 & 4 & 4 & 1 & 9 & 5 \\
\hline 3 & & 6 & 3 & 3 & 2 & 9 & 5 \\
\hline 4 & & 7 & 8 & 4 & 4 & 15 & 8 \\
\hline 5 & & 7 & 3 & 2 & 2 & 10 & 4 \\
\hline 6 & & 5 & 3 & 4 & 2 & 8 & 6 \\
\hline 7 & & 8 & 1 & 1 & 4 & 9 & 5 \\
\hline 8 & & 4 & 3 & 5 & 2 & 7 & 7 \\
\hline 9 & & 4 & 3 & 5 & 2 & 7 & 7 \\
\hline 10 & & 8 & 10 & 3 & 2 & 18 & 5 \\
\hline 11 & . & 8 & 6 & 3 & 6 & 14 & 9 \\
\hline 12 & & 11 & 5 & 2 & 5 & 16 & 7 \\
\hline 13 & & 10 & 1 & 1 & 11 & 11 & 12 \\
\hline $14^{*}$ & & 11 & 5 & 0 & 6 & 16 & 6 \\
\hline 15 & & 6 & 10 & 5 & 2 & 16 & 7 \\
\hline 16 & & 7 & 8 & 4 & 4 & 15 & 8 \\
\hline 17 & & 9 & 1 & 0 & 4 & 10 & 4 \\
\hline 18 & & 8 & 2 & 1 & 3 & 10 & 4 \\
\hline 19 & & 11 & 12 & 0 & 0 & 23 & $\mathbf{0}$ \\
\hline $20^{*}$ & & 6 & 9 & 5 & 2 & 15 & 7 \\
\hline 21 & & 10 & 1 & 1 & 11 & 11 & 12 \\
\hline 22 & & 5 & 3 & 4 & 2 & 8 & 6 \\
\hline$X$ & & 11 & 0 & 0 & 12 & 11 & 12 \\
\hline
\end{tabular}

++ , Human C3 expressed (chromosome present); -, human C3 not expressed (chromosome not present); +-, human C3 expressed (chromosome not present); - +, human C3 not expressed (chromosome present). Data are summarized from karyotype and/or enzyme marker analysis of 23 human-mouse somatic cell hybrid subclones [110]

analysis using the pxHu C3 pst 1.39 probe. RFLPs were detected for the enzymes Sst I, Taq I, Bgl II [27] and Sst I, Taq I, and Hind II (Wieacker, Wienker, Grimm, Bender, Rogers, and Fey, unpublished data). In family studies linkage was detected between the $\mathrm{C} 3$ protein polymorphisms, C3-RFLPs and DM [27], and C3RFLPs/DM and C3-RFLPs/SE as well as linkage SE/DM and DM/LE (Wieacker, Wienker, Grimm, Bender, Rogers, and Fey, unpublished results; and Roses, Pericak-Vance, Yamaoka, Carter, Stajich, Vance, Conneally, Stubblefield, and Fey, unpublished data). From these data it appears that the C3-RFLPs provide good markers for the description of the region of chromosome 19 around the DM locus.

Finally, initial results have been obtained in experiments to determine more precisely the location of the C3 locus on chromosome 19 . Using somatic cell hybrids with $\mathrm{x} / 19$ translocations, a map position of the C3 locus on the distal long arm of chromosome 19 (19 q 133-19 q ter) could be excluded (Wieacker, Fey, Voiculescu, and Ropers, unpublished data). By similar analyses it may be possible in the future to further refine the location and the orientation of this linkage group on chromosome 19. 
Table 2. Segregation of hybridization of the DNA probe pxHuC3 1.39/132 to EcoRI-digested DNA from eight somatic cell hybrid subclones

\begin{tabular}{|c|c|c|c|c|c|c|}
\hline \multirow{3}{*}{$\begin{array}{l}\text { Human } \\
\text { chromo- } \\
\text { some }\end{array}$} & \multicolumn{6}{|c|}{ Hybridization of probe } \\
\hline & \multicolumn{2}{|c|}{ Concordant } & \multicolumn{2}{|c|}{ Discordant } & \multicolumn{2}{|l|}{ Total } \\
\hline & ++ & -- & +- & -+ & Concordant & Discordant \\
\hline 1 & 4 & 0 & 0 & 4 & 4 & 4 \\
\hline 2 & 2 & 3 & 2 & 1 & 5 & 3 \\
\hline 3 & 2 & 2 & 2 & 2 & 4 & 4 \\
\hline 4 & 2 & 0 & 2 & 4 & 2 & 6 \\
\hline 5 & 3 & 2 & 1 & 2 & 5 & 3 \\
\hline 6 & 1 & 2 & 3 & 2 & 3 & 5 \\
\hline 7 & 4 & 0 & 0 & 4 & 4 & 4 \\
\hline 8 & 1 & 2 & 3 & 2 & 3 & 5 \\
\hline 9 & 1 & 2 & 3 & 2 & 3 & 5 \\
\hline 10 & 3 & 2 & 1 & 2 & 5 & 3 \\
\hline 11 & 2 & 4 & 2 & 0 & 6 & 2 \\
\hline 12 & 4 & 0 & 0 & 4 & 4 & 4 \\
\hline 13 & 3 & 0 & 1 & 4 & 3 & 5 \\
\hline 14 & 4 & 0 & 0 & 4 & 4 & 4 \\
\hline 15 & 2 & 2 & 2 & 2 & 4 & 4 \\
\hline 16 & 3 & 2 & 1 & 2 & 5 & 3 \\
\hline 17 & 4 & 0 & 0 & 4 & 4 & 4 \\
\hline 18 & 3 & 1 & 1 & 3 & 4 & 4 \\
\hline 19 & 4 & 4 & 0 & 0 & 8 & 0 \\
\hline 20 & 3 & 2 & 1 & 2 & 5 & 3 \\
\hline 21 & 4 & 0 & 0 & 4 & 4 & 4 \\
\hline 22 & 1 & 2 & 3 & 2 & 3 & 5 \\
\hline 23 & 4 & 0 & 0 & 4 & 4 & 4 \\
\hline
\end{tabular}

++ , Probe hybridizes (chromosome present); - , probe does not hybridize (chromosome not present); +- , probe hybridizes (chromosome not present); -+ , probe does not hybridize (chromosome present). Data are summarized from karyotype and/or enzyme marker analysis of eight human-mouse somatic cell hybrid subclones [110]

4) A Family Presenting Inherited Human C3 Deficiency. Inherited partial and total C3 deficiencies in man and higher animals have been described but they are rare [6, $113,114]$. The field has been carefully reviewed $[3,5]$; therefore we restrict ourselves here to a few selected observations. The standard concentration of $\mathrm{C} 3$ in human serum ranges from 1 to $2 \mathrm{mg} / \mathrm{ml}$. In comparison, heterozygous deficient individuals have serum levels reduced to half normal values. If one admits the single locus model of the $\mathrm{C} 3$ gene, these observations can be explained by postulating one completely inactive allele (null allele) and one co-dominantly expressed normal allele [69, 77]. Partial deficiencies would imply a partially inactive gene product or partially reduced synthesis of a normal product from at least one defective allele. Carriers of partial deficiency are generally healthy. Only minor defects in complementmediated functions can be detected in their serum. The residual C 3 concentration is apparently sufficient to maintain the essential defense and immune regulatory functions of $\mathrm{C} 3$. 


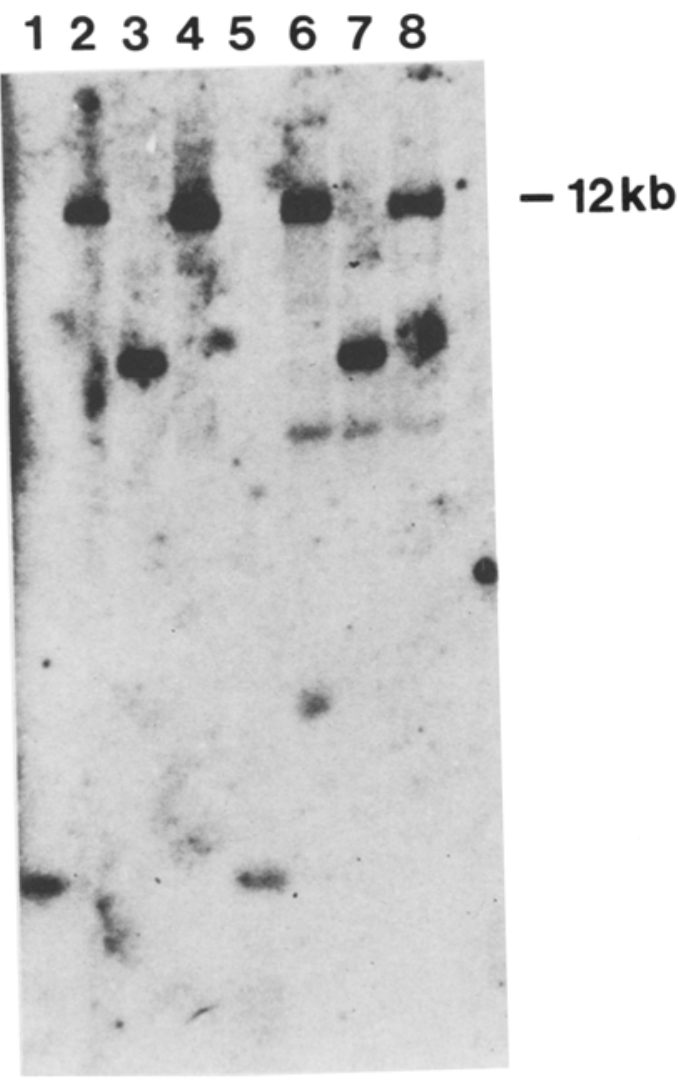

Fig. 9. The human C3 gene is not somatically rearranged. DNA was prepared from sperm cells and peripheral blood cells of the same human donor, and digested separately with one of the four different restriction endonucleases: PstI, HindIII, BamHI, and EcoRI. The fragments were separated by electrophosesis in an agarose gel and subsequently transferred to a nitrocellulose filter (Southern blot). The filter was hybridized with nicktranslated plasmid DNA from plasmid pxHuC3 Pst 1.39 carrying a nonrepetitive sequence (probably exon-DNA) of the human C3 gene [110]. Size markers were contained in the same gel, and the position of the diagnostic $12 \mathrm{~kb}$ EcoRI fragment of the human C3 gene is indicated. Tracks 1 to 4 : sperm DNA digested with Pstl, HindIII, BamHI, and EcoRI. Tracks 5 to 8: blood cell DNA digested with the same enzymes

Total (homozygous) $\mathrm{C} 3$ deficiency in man is very rare. Only approximately half a dozen families of this kind have been reported $[6,8,9,11,28,43,46,76,81,85]$. In affected individuals, the complete absence of $\mathrm{C} 3$ is usually associated with such recurrent, pyogenic infections as pneumonia, septicemia, otitis media, and meningitis $[8,9,11,28,43,46,76,81,85]$. Several individuals with a total $C 3$ deficiency have died as children from severe infections. Replacement of functional C3 by transfusion of normal plasma into deficient patients transiently eliminates the symptoms of these systemic infections [76]. Sera from several homozygous C3 deficient subjects studied in vitro showed a significant reduction or absence of most complement-mediated functions such as hemolytic activity for antibody-sensitized sheep red blood cells, opsonization of endotoxin particles, and chemotactic and bactericidal activities $[8,9,85]$. Reconstitution of the deficient sera with purified normal $\mathrm{C} 3$ compensated for these defects.

The most recently published study describes a Dutch family [85] whose pedigree is reproduced in Fig. 10, with the kind permission of Dr. John Roord and colleagues, University Hospitals, Utrecht and Leiden, The Netherlands. Both parents are considered heterozygous deficient by virtue of the reduced $\mathrm{C} 3$ concentrations in their sera and the inheritance pattern of this deficiency in their offspring. The parents are related in the seventh degree. They never exhibited serious illness and 


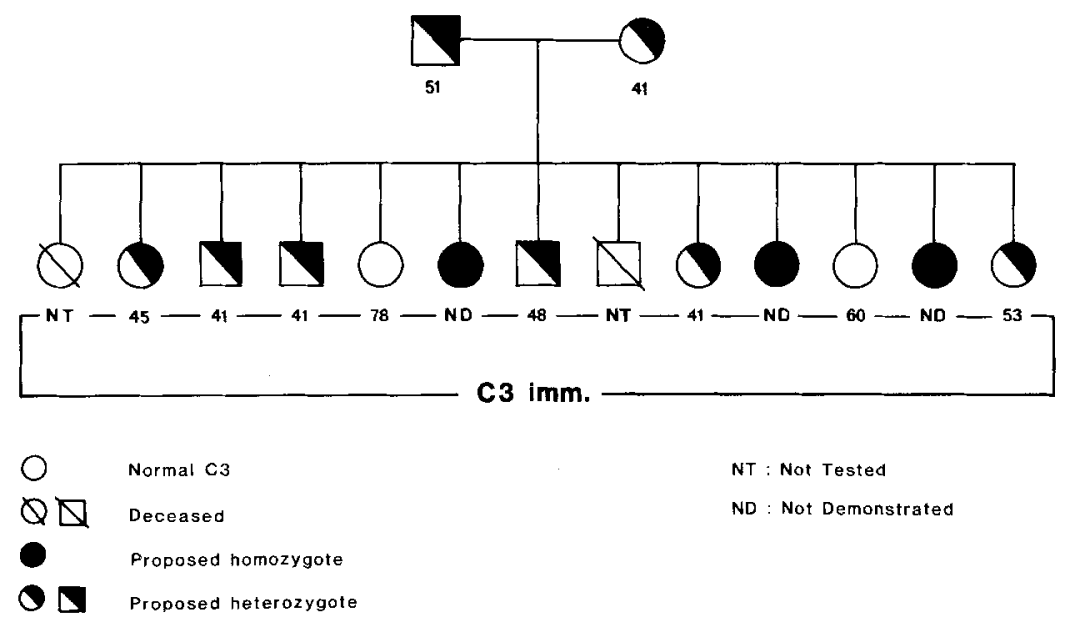

Fig. 10. A family with interited $C 3$ deficiency. Family tree of the Dutch kindred presenting three members with inherited total C3 deficiency, described by Roord and colleagues [85]. Numbers give the serum concentrations of immunochemically detected C3 in $\mathrm{mg} / 100 \mathrm{ml}$. (With kind permission from Dr. J. Roord and colleagues)

are free from clinical symptoms. Two of their 13 children died, one at the age of three years from bacterial meningitis and the other at the age of six years in a car accident. This child had no history of recurrent infections. However, three of the remaining children have recurring severe infections; one suffers from severaly impaired motor and mental development that began after the first of three episodes of meningitis. Other than this impairment a long-term regimen of ampicillin prophylaxis kept these patients well, until an attempt to discontinue the antibiotics resulted in renewed infections in two of the patients that necessitated resumption of continuous antibiotic prophylaxis. These three patients have no immunochemically detectable $\mathrm{C} 3$ antigen in their sera and only $1-2 \%$ of normal $\mathrm{C} 3$ hemolytic functional activity. Six of the other children are presumably heterozygous deficient; another two are normal. These eight are free from symptoms and have no history of recurrent infection.

Until now, none of the inherited defects leading to partial or total C3 deficiency have been mapped to the structural locus coding for the $\mathrm{C} 3$ protein. Also, there are no well-documented reports of $\mathrm{C} 3$ protein mutants, although one recent publication contains circumstantial evidence for a structural mutation of the $\mathrm{C} 3$ protein [57].

To further define the molecular nature of defects leading to inherited C3 deficiencies, the first necessity is to map the site of mutation. Then one must distinguish between second-site mutations (affecting a control locus involved in the expression of the $\mathrm{C} 3$ gene or the biosynthesis of the $\mathrm{C} 3$ protein) and structural mutations in the coding sequences for the $\mathrm{C} 3$ protein. On the DNA level, such major alterations of the structural gene as deletions, insertions, or rearrangements are generally detectable by comparative Southern blot analysis with DNA from deficient and normal individuals. These studies have been difficult to perform in the 
past due to the limited amounts of DNA available from the patients. To generate an unlimited supply of DNA from members of the Dutch family, peripheral blood Blymphocytes from seven family members were transformed with Epstein-Barr Virus (Drs. Yvonne Boyd, D. Hunter, and J. Edwards, unpublished data; personal communication). Cell-lines were established in culture from one of the parents, all three homozygous deficient children, two that were heterozygous, and one normal child. These cell lines will be used for the analysis of the defect at the DNA level.

\section{Expression of the C3 Gene}

\section{A. Tissue Specific Expression}

The $\mathrm{C} 3$ gene is subject to several levels of control. Most obvious is the restriction of its expression to production to only a few tissues. In addition, hormones and also inflammatory signals control the quantities of $\mathrm{C} 3$ circulating in the bloodstream and, therefore, probably the rates of synthesis in the producer tissues.

The bulk of the circulating serum $\mathrm{C} 3$ is synthesized in the liver. Alper and colleagues convincingly demonstrated this point by assaying plasma proteins following orthotopic liver transplantation [7]. By taking advantage of the structural polymorphisms of $\mathrm{C} 3, \mathrm{C} 6, \mathrm{C} 8$, and factor $\mathrm{B}$, they showed that more than $90 \%$ of the circulating forms of these proteins are synthesized in the liver. In addition, synthesis of $\mathrm{C} 3$ was demonstrated in primary hepatocyte cultures and in hepatoma cell lines $[23,36,52,64,65,93]$ (Fig. 11, tracks 3 and 4). These data strongly suggest that the hepatocytes are the major site of synthesis of $\mathrm{C} 3$. The percentage of hepatocytes involved in $\mathrm{C} 3$ synthesis under normal and inflammatory conditions is unknown.

C3 is also synthesized outside of the liver. Fragments of synovial tissues obtained from patients with rheumatoid arthritis were capable of synthesizing functional $\mathrm{C} 3$ as well as $\mathrm{C} 4$ and factor $\mathrm{B}$, whereas similar tissues from patients with degenerative or traumatic joint diseases failed to synthesize $\mathrm{C} 3$ in detectable amounts [87]. Other secondary sites of $\mathrm{C} 3$ synthesis include macrophages [21, 22, $37]$ monocytes [34, 108], spleen cells, lymphoid cells, and other tissues of the reticuloendothelial systems as well as a few epithelial cell types $[90,101]$ and fibroblasts in tissue cultures [90, 109]. Gut-associated cells (hepatocytes and epithelial cells of the genitourinary and intestinal tracts) and cells of the reticuloendothelial system (macrophage/monocyte series) are the principal producers not only of $\mathrm{C} 3$ but also of most of the other complement proteins $[23,36]$.

Preliminary evidence has been presented to demonstrate the synthesis, but not the secretion, of several complement components by peripheral blood lymphocytes [94]. Peripheral blood monocytes synthesize and secrete C2, C3, C4, C5 factors B, $\mathrm{D}, \mathrm{P}, \mathrm{I}$, and $\mathrm{H}$ as antigenically recognizable products and functionally active $\mathrm{C} 2, \mathrm{~B}$, $\mathrm{P}, \mathrm{D}$, and I. However, these cells do not secrete functionally active C3, C4, C5, C6, C7, or C9 in conventional tissue cultures $[34,108]$.

The molecular differences in $\mathrm{C} 3$ protein synthesized by monocytes that render this product funtionally inactive compared to $\mathrm{C} 3$ from hepatocytes are unknown. The quality in question may be a different pathway of $\mathrm{C} 3$ biosynthesis in these two tissues. Circumstantial evidence supporting this idea has been provided by a report 


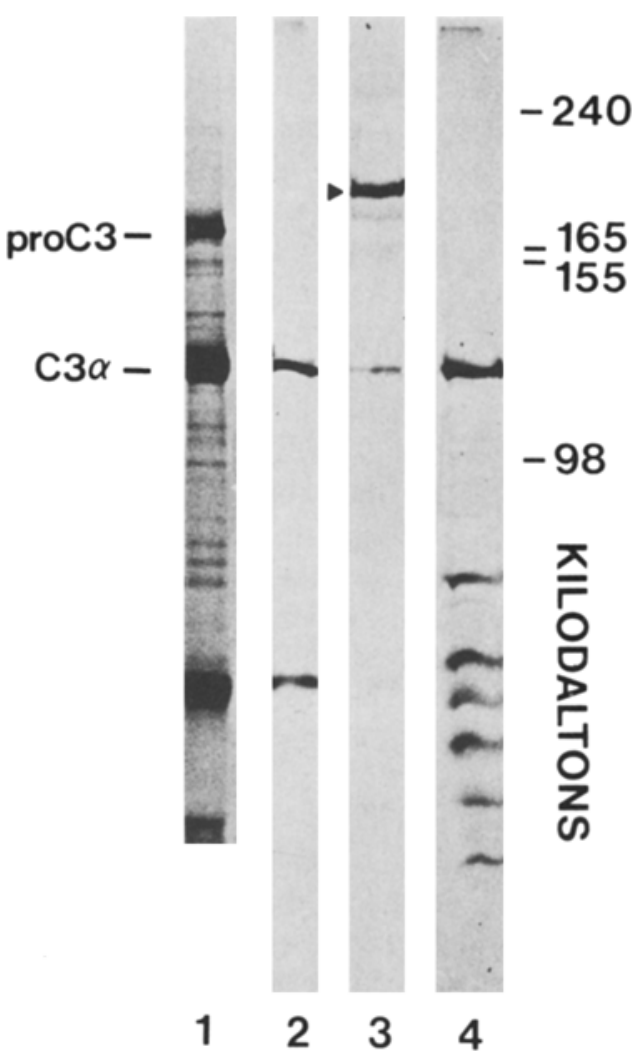

Fig. 11. Expression of $\mathrm{C} 3$ in two established macrophage-like and two rat hepatoma cell lines in tissue cultures. Culture conditions were as previously described for primary macrophages [37]. Cells were metabolically labeled by adding $50-120 \mu \mathrm{Ci}$ of ${ }^{35} \mathrm{~S}$ methionine $\left(10^{3} \mathrm{Ci} / \mathrm{mmol}\right)$ per $9 \mathrm{~cm}$ diameter dish, incubating for $1.5 \mathrm{~h}$, followed by a chase for $1.5 \mathrm{~h}$ after the addition of unlabeled methionine to a final concentration of 300 $\mu \mathrm{M}$. Tissue culture supernatants were collected, centrifuged to remove floating cells, and brought to $10 \mathrm{mM}$ in $\mathrm{N}$-acetylmaleimide. In the experiment shown in tracks $2-4$, the tissue culture supernatants were passed three times over a gelatinSepharose column to remove fibronectin [115]. Immunoprecipitation was performed with commercial (Nordic, Tilburg, The Netherlands) rabbit anti-rat BIC (C3) serum. The immunoprecipitates were analyzed by SDS-polyacrylamide gel electrophoresis as described previously $[37,74]$. Track 1: direct immunoprecipitate from IC 21 cells [58]. Tracks 2 to 4 : indirect immunoprecipitates from J774.2 cells [68], HTCcells [100] and FaO cells [30], respectively. The positions of the precursor proC 3 and the mature C3 $\alpha$ are indicated. The 200000 molecular weight protein coprecipitated with the immunoprecipitate from HTC cells (arrow in Track 3) has not been identified

of inherited $\mathrm{C} 3$ deficiency. The case concerns a patient whose serum levels of $\mathrm{C} 3$ were less than $1 \%$ of normal [34]; therefore, the hepatic pathway of production must have been severely affected by a mutation. However, peripheral blood monocytes taken from this patient and placed in primary tissue culture synthesized $25 \%$ of normal amounts of a C3 molecule, with apparently normal size and subunit composition. Therefore, the monocyte pathway of $\mathrm{C} 3$ biosynthesis may not have been as severely affected by the mutation as that of the liver. The appropriate control, in vitro biosynthesis of $\mathrm{C} 3$ by primary hepatocytes from this individual, could not be performed because the cells were not available. One direct attempt was made to determine whether hepatocytes and macrophage/monocytes synthesize different $\mathrm{C} 3$ molecules. However, after analyzing the spectrum of isoelectric variants of human $\mathrm{C} 3$ from monocyte culture supernatants and from serum by immunofixation in isoelectric focusing gels, no difference was observed (Shiels and Hobart, personal communication). Thus, an interesting problem remains to determine why the human monocyte $\mathrm{C} 3$ product is hemolytically inactive, exactly how it differs from the liver product and what its physiologic role can be. Even if monocyte C3 lacks hemolytic activity, it should provide an adequate source of $\mathrm{C} 3$-derived peptide fragments, such as C3a. Therefore, one might reasonably speculate that an important role of the $\mathrm{C} 3$ polypeptide synthesized by peripheral cells might be to 
serve in the amplification of localized inflammatory responses in order to confine peripheral centers of inflammation. Such a role for fibroblast derived C3 has previously been proposed [109].

The C 3 gene provides a useful model for the study of the molecular mechanisms of tissue-specific gene expression for several reasons. First, there is a clear-cut difference in its expression in nonproducer and producer tissues; in the main producer tissue, liver hepatocytes, the gene is abundantly expressed. Second, apparently several types of producer tissues exist (major and minor producers) with possible molecular differences in the $\mathrm{C} 3$ protein that they produce. Finally, primary cells from several producer tissues continue to express $\mathrm{C} 3$ in culture (macrophages, monocytes, fibroblasts, synovial cells), and established hepatoma cell lines exist that secrete C3. Also, specific antisera, cloned cDNA, and genomic DNA sequences are available as tools to monitor gene expression. Recently, this range of tools has been further extended by the demonstration of $\mathrm{C} 3$ synthesis in two permanently established mouse macrophage tissue culture cell-lines [74] (Fig. 11, tracks 1 and 2). These cell lines, IC 21 and $\mathbf{J} 774.2$, other than producing C3 possess several other characteristic properties of differentiated macrophages $[58,68]$. The ultimate goal of comparative studies with all these cells would be to explain at the molecular level the mechanisms that lead to differential expression of the $\mathrm{C} 3$ gene in various tissues.

\section{B. Induction of C3 Synthesis in Acute Inflammation}

Several of the complement components are acute phase reactants in the sense that their serum concentrations increase during severe acute and chronic inflammation and after major tissue damage and surgery $[53,66]$. C2, C3, C4, C5b, C9, and factor $\mathrm{B}$ have been reported to increase in concentrations during infection and tissue injury $[1,12,97]$. Concentrations of some acute phase reactants such as $\mathrm{C}$-reactive protein (CRP) and serum amyloid A-protein (SAA) begin to rise very rapidly (within a few hours after injury), whereas levels of $\mathrm{C} 3$ and ceruloplasmin rise more slowly (within 2-10 days). The acute phase proteins also differ markedly in the magnitude of their increase in concentration after stimulus. Concentrations of $\mathrm{C} 3$ increase about $50 \%$ (from a normal value of $1.0-1.9 \mathrm{mg} / \mathrm{ml}$ to $2.2-2.6 \mathrm{mg} / \mathrm{ml}$ ), whereas concentrations of CRP and SAA may increase several hundred-fold. C3 was reported to rise to 2.7 $\mathrm{mg} / \mathrm{ml}$ within eight days in persons with bacterial meningitis, to $2.2 \mathrm{mg} / \mathrm{ml}$ in four to eight days in those with acute pyelonephritis and systemic lupus erythematosus, to $2.95 \mathrm{mg} / \mathrm{ml}$ in those with gonococcal arthritis, and to $2.2 \mathrm{mg} / \mathrm{ml}$ within one to two days after major surgery [54]. These values return to normal within a few days after disappearance of the inflammation. Because consumption of $\mathrm{C} 3$ usually increases as well, one may expect that the overall rate of synthesis may increase by more than $50 \%$. It is not known whether the heightened serum concentrations result from a faster rate of synthesis in only those cells that were synthesizing C3 before the onset of inflammation, or whether additional hepatocytes and possibly other types of producer cells (e.g., macrophages) are recruited for synthesis. Most of the acute phase plasma proteins are liver products, therefore, it might be expected that the majority of the newly synthesized C 3 appearing in serum during the acute phase response is made by the liver. Many acute phase products of hepatocyte origin can be induced by Interleukin 1 [15] and a spectrum of other agents including glucocorticoids, synthetic steroid hormones, thyroxin, insulin, and breakdown 
fragments of fibrinogen [40]. However, no single major inflammatory inducer of C3 has been identified and well-characterized except for one report of $\mathrm{C} 3$ regulation by a glucocorticoid hormone [93].

\section{Involvement of Hormones in the Control of C3 Production}

C3 concentrations are influenced by hormones. In humans, total amounts of complement activity and $\mathrm{C} 3$ increase significantly in maternal sera late in pregnancy [79]. Also, Strunk and colleagues [93] reported that the biosynthesis of C3 increased up to nine-fold after adding hydrocortisone succinate to cultured rat hepatoma cells, although the production of $\mathrm{C} 3$ and $\mathrm{C} 5$ in these cultures was not affected. This effect was observed in only one of four different $\mathrm{C} 3$ producing strains, the H4 hepatoma cell line. We have attempted to produce a similar effect with dexamethasone on two different established rat hepatoma cell lines, $\mathrm{FaO}[30]$ and $\mathrm{HTC}[100]$. One of these, $\mathrm{FaO}$, is a subline of the hepatoma from which the $\mathrm{H} 4$ line originated. Although both lines synthesized readily detectable amounts of $\mathrm{C} 3$ (Fig. 11, tracks 3 and 4), no increase resulted. Instead, a two-fold decrease of $\mathrm{C} 3$ synthesis was observed, indicating that the published effect was specific for the particular cell line and possibly the particular derivative of the hormone that was used in the original study [93].

A variety of biosynthetic and secretory functions of macrophages can be regulated by dexamathasone $[18,103,106,107]$. Because we had detected $\mathrm{C} 3$ synthesis in two established mouse macrophage-like cell lines [74] (Fig. 11, tracks 1 and 2), we determined whether dexamethasone would affect the synthesis and secretion of $\mathrm{C} 3$ in the $\mathrm{J} 774.2$ cell line. Synthesis and secretion both diminished approximately two-fold in a dose dependent manner with half maximal effect reached at a hormone concentration of $10^{-7} \mathrm{M}$. This effect was partially reversible and both intracellular proC3 and extracellular native $\mathrm{C} 3$ were reduced to similar extents. Surprisingly, the C $3 \mathrm{mRNA}$ concentrations were reproducibly increased 1.5-fold under the same conditions. The mRNA concentrations were determined in quantitative Northern blot hybridizations by using radiolabeled, cloned cDNA probes for mouse C3 (Fig. 12A tracks 3 and 4). The control [staining of the same tracks of the gel with ethidium bromide (Fig. 12A tracks 1 and 2)] showed that equivalent amounts of total mRNA were contained in these tracks. The resulting data indicate that the hormone may affect the $\mathrm{C} 3 \mathrm{mRNA}$ and protein production in opposite ways. The hybridizations were calibrated with total mouse liver mRNA (Fig. 12A, tracks 5 to 7, Fig. 12B). The results show that this RNA assay is sufficiently sensitive to detect a two-fold change in $\mathrm{C} 3 \mathrm{mRNA}$ concentration. With these new tools, a variety of experiments can now be performed to quantitate the tissuespecific and inflammation controlled expression of the $\mathrm{C} 3$ gene into primary transcripts and mature mRNA.

\section{Summary}

To map the multiple interactive sites on the $\mathrm{C} 3$ polypeptide, it is advantageous to combine the approaches of protein chemistry, nucleic acid technology, and 

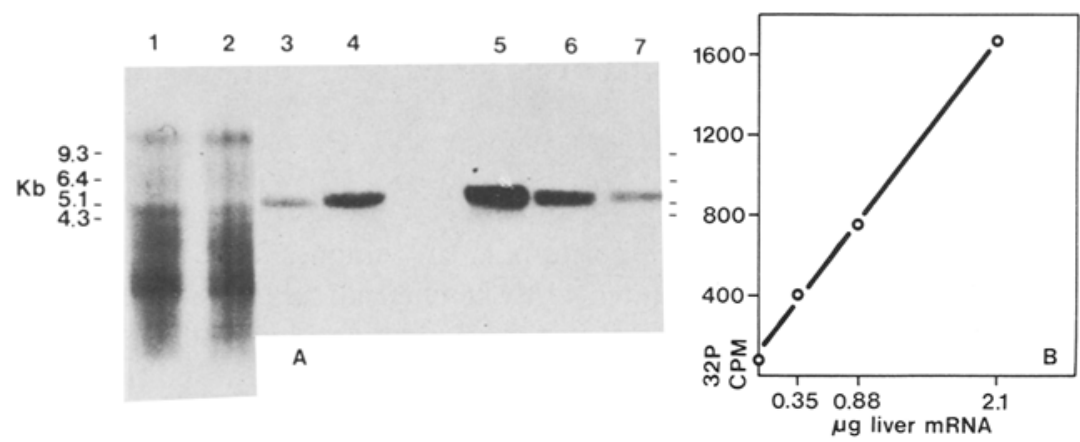

Fig. 12. Titration of $\mathrm{C} 3 \mathrm{mRNA}$ in hormone-treated macrophage-like cells. For calibration purposes mouse liver RNA was extracted and mRNA was enriched by oligo-dT cellulose chromatography as described previously [75]. Total cellular RNA was extracted from cells (J774.2) in tissue culture with hot phenol and subsequently enriched for polyadenylated mRNA [88]. RNA samples were denatured in glyoxal [60], electrophoresed in agarose gels, and transferred to nitrocellulose (Northern blot) as described previously [31]. Nicktranslated mouse C3 cDNA plasmid pMLC3-1 (Fig. 1) was used as hybridization probe. Panel $A$ : Tracks 1, 2: mRNA from J 774.2 cells, before hybridization, stained with ethidium bromide, Tracks 3-7: autoradiographs after hybridization of the Northern blots. Tracks 1 and $3: 9 \mu \mathrm{g}$ of mRNA from J774.2 cells; Tracks 2 and $4: 9 \mu \mathrm{g}$ of mRNA from J774.2 cells treated for $48 \mathrm{~h}$ with $10^{-6} \mathrm{M}$ dexamethasone. Tracks 5-7: decreasing amounts of mouse liver mRNA: $2.1 \mu \mathrm{g}, 0.88 \mu \mathrm{g}$ and 0.35 $\mu \mathrm{g}$, respectively. Panel B: Calibration. The amounts of hybridized radioactive probe from tracks $5-7$, Panel A were quantitated by excision of corresponding regions of the nitrocellulose filter after autoradiography and by counting in liquid scintillation cocktail

molecular biology. This review summarizes the currently known molecular properties of mouse liver C3 mRNA, cloned C3 cDNA, and genomic DNA. Original data communicated have specified the amino acid sequence of the 215 aminoterminal residues of mature mouse $\mathrm{C} 3 \beta$. Southern blot analysis of liver DNA indicated that the mouse genome contains only one type of $\mathrm{C} 3$ gene, that murine and human C3 sequences strongly cross-hybridize, and that the human C3 gene is not somatically rearranged. Included are descriptions of the first human $\mathrm{C} 3$ genomic DNA clones, their preparation, and their use to map the human C3 gene to chromosome 19 in linkage with the myotonic dystrophy (DM) locus. After a brief survey of reports describing inherited human $\mathrm{C} 3$ deficiencies, we discuss a Dutch family and their three members with total homozygous C3 deficiency who were the subjects of a recent publication. The restricted synthesis of $\mathrm{C} 3$ in major and minor producer tissues is discussed and it is proposed that the $\mathrm{C} 3$ gene provides a good model system for studying the molecular basis of tissue-specific gene expression. Data are presented documenting the production of C3 in two established mouse macrophage-like cell lines and two rat hepatoma cell lines in tissue cultures. A short account covers the extensive literature on regulation of $\mathrm{C} 3$ serum concentrations in acute and chronic inflammation and the very incomplete picture that presently depicts hormonal regulation of $\mathrm{C} 3$ synthesis. The final experiment reported demonstrates that nucleic acid hybridization with cloned cDNA probes is a sensitive assay for quantitative determinations of C3 mRNA. With the help of cloned cDNA and genomic DNA, researchers can address questions concerning the 
functional topography of the C3 polypeptide, the gene's structure, and the molecular nature of inherited $\mathrm{C} 3$ deficiencies in humans.

Acknowledgements. We are indebted to Drs. Boyd, Dodd, Davies, Edwards, Hobart, Mohr, Roord, Rittner, Ropers, Roses, Shiels, and Wieacker for communication of results prior to publication and for permission to cite these here. We thank our colleagues and the staff of the Swiss Cancer Research Institute and the Research Institute of Scripps Clinic for support and discussions. In particular we acknowledge Verena Muller for technical assistance, Phyllis Minick, Keith Dunn, and Ellen Schmeding for helping to edit and prepare the manuscript. This work was funded by Research Grants from the Swiss National Science Foundation and from the National Institutes of Health, National Institute of Allergy and Infectious Disease Grant No. 1RO1 AI 19651-01. Drs. Domdey and Wiebauer were recipients of postdoctoral fellowships from the Deutsche Forschungsgemeinschaft and the European Molecular Biology Organization, respectively. Dr. Karel Odink was supported by a fellowship from the Swiss Cancer Research Institute.

\section{References}

1. Alexander JW, Ogle CK, Stinnett JD, MacMillan BG (1978) A sequential, prospective analysis of immunologic abnormalities and infection following severe thermal injury. Ann Surg 188: 809

2. Alper CA (1973) Genetics and the C3 molecule. Vox Sang 25: 1

3. Alper CA (1984) Complement deficiencies and genetic polymorphisms. Springer Semin Immunopathol 7: in press

4. Alper CA, Propp RP (1968) Genetic polymorphism of the third component of human complement (C'3). J Clin Invest 47: 2181

5. Alper CA, Rosen FS (1981) Complement deficiencies in humans. In: Franklin EC (ed) Clinical immunology update. Elsevier, New York, pp 59-75

6. Alper CA, Propp RP, Klemperer MR, Rosen FS (1969) Inherited deficiency of the third component of human complement (C'3). J Clin Invest 48: 553

7. Alper CA, Johnson AM, Birtch AG, Moore FD (1969) Human C'3: evidence for the liver as the primary site of synthesis. Science 163: 286

8. Alper CA, Colten HR, Rosen FS, Robson AR, Macnab GM, Gear JSS (1972) Homozygous deficiency of $\mathrm{C} 3$ in a patient with repeated infections. Lancet II: 1179

9. Alper CA, Colten HR, Gear JJS, Rabson AR, Rosen FS (1976) Homozygous human C3 deficiency. J Clin Invest 57: 222

10. Austen BM (1979) Predicted secondary structures of amino-terminal extension sequences of secreted proteins. FEBS Lett 103: 308

11. Ballow M, Shira JE, Harden L, Yang SY, Day NK (1975) Complete absence of the third component of complement in man. $\mathrm{J}$ Clin Invest 56: 703

12. Bamberger J, Freed DLJ, Banks AJ, Maltby B (1978) Systemic complement fixation after fractures. Lancet 1: 395

13. Blobel G, Dobberstein B (1975) Transfer of proteins across membranes. I. Presence of proteolytically processed and unprocessed nascent immunoglobulin light chains on membrane-bound ribosomes of murine myeloma. J Cell Biol 67: 835

14. Bolivar F, Rodriguez RL, Greene PJ, Betlach MC, Heyneker HL, Boyer HW, Corosa JH, Falkow S (1977) Construction and characterization of new cloning vehicles: a multipurpose cloning system. Gene 2: 95

15. Bornstein DL (1982) Leucocytic pyrogen: a major mediator of the acute phase reaction. Ann NY Acad Sci 389: 323

16. Brade V, Hall RE, Colten HR (1977) Biosynthesis of proC3, a precursor of the third component of complement. J Exp Med 146: 759

17. Campbell RD, Gagnon J, Porter RR (1981) Amino acid sequence around the thiol and reactive acyl groups of human complement component C4. Biochem J 199: 359

18. Carlson Seifert S, Gelehrter TD (1978) Mechanism of dexamethasone inhibition of plasminogen activator in rat hepatoma cells. Proc Natl Acad Sci USA 75: 6130 
19. Carroll MG, Capra JD (1979) Molecular weight variations in the polypeptide subunits of the third and fourth components of complement derived from various mammalian species. Fed Proc 38: 1291

20. Chan AC, Mitchell KR, Munns TW, Karp DR, Atkinson JP (1983) Identification and partial characterization of the secreted form of the fourth component of human complement: evidence that it is different from the major plasma form. Proc Natl Acad Sci USA 80: 268

21. Cole FS, Matthews WY, Marino JT, Gash DY, Colten HR (1980) Control of complement synthesis and secretion in bronchoalveolar and peritoneal macrophages. J Immunol 125: 1120

22. Cole FS, Beatty D, Davis AE, Colten HR (1980) Complement synthesis by human breast milk macrophages and blood monocytes. Fed Proc 39: 1200

23. Colten HR (1976) Biosynthesis of complement. Adv Immunol 22: 67

24. Colten HR, Ooi YM, Edelson PJ (1979) Synthesis and secretion of complement proteins by macrophages. Ann NY Acad Sci 332: 482

25. Corbin NC, Hugli TE (1976) The primary structure of porcine C3a anaphylatoxin. J Immunol 117: 990

26. Corden J, Wasylyk B, Buchwalder A, Sassone-Corsi P, Kedinger C, Chambon P (1980) Promoter sequences of eucaryotic protein-coding genes. Science 209: 1406

27. Davies KE, Jackson J, Williamson R, Harper PS, Ball S, Sarfarazi M, Meredith L, Fey GH (1983) Linkage analysis of myotonic dystrophy and sequences on chromosome 19 using a cloned complement 3 gene probe. J Med Genet (in press)

28. Davis AE, Davis JS, Rabson AR, Osofsky SG, Colten HR, Rosen FS, Alper CA (1977) Homozygous C3 deficiency: Detection of C3 by radioimmunoassay. Clin Immunol Immunopathol 8: 543

29. Deininger PL, Jolly DY, Rubin CM, Friedmann T, Schmid CW (1981) Base sequence studies of 300 nucleotide renatured repeated human DNA clones. J Mol Biol 157: 17

30. Deschatrette J, Moore EE, Dubois M, Cassio D, Weiss MC (1979) Differentiated variants of a rat hepatoma: analysis by cell hybridization. Somatic Cell Genet 5: 697

31. Domdey H, Wiebauer K, Kazmaier M, Muller V, Odink K, Fey G (1982) Characterization of the mRNA and cloned cDNA specifying the third component of mouse complement. Proc Natl Acad Sci USA 79: 7619

32. Eiberg H, Mohr J, Staub Nielsen L, Simonsen N (1982) Linkage relationship between the locus for $\mathrm{C} 3$ and 50 polymorphic systems: assignment of $\mathrm{C} 3$ to the DM-DE-LU linkage group: confirmation of C3-LES linkage; support of LE-DM synteny. Proc VI Inter Cong Hum Genet (Jerusalem, 1981). Alan Liss, New York

33. Eiberg H, Mohr J, Staub Nielsen L (1982) Indication of linkage between the PEPD locus and the C3LE-DM-SE-LU linkage group (and support for assignment of this linkage group to chromosome nr. 19). Abstract ESHG-Meeting, Madrid. Personal Communication

34. Einstein LP, Hansen PJ, Ballow M, Davis AE, Davis JS, Alper CA, Rosen FS, Colten HR (1977) Biosynthesis of the third component of complement (C3) in vitro by monocytes from normal and homozygous $\mathrm{C} 3$-deficient humans. J Clin Invest 60: 963

35. Fearon DT (1983) The human C3b receptor. Springer Semin Immunopathol 6:

36. Fey G, Colten HR (1981) Biosynthesis of complement components. Fed Proc 40: 2099

37. Fey GH, Odink K, Chapuis RM (1980) Synthesis of mouse complement component C4 (SS-protein) by peritoneal macrophages: kinetics of secretion and glycosylation of the subunits. Eur J Immunol 10: 75

38. Fey GH, Wiebauer K, Domdey H (1983) Amino acid sequences of mouse complement C3 derived from nucleotide sequences of cloned cDNA. Ann NY Acad Sci (in press)

39. Fritsch EF, Lawn RM, Maniatis T (1980) Molecular cloning and characterization of the human $\beta$ like globin gene cluster. Cell 19: 959

40. Fuller GM, Ritchie DG (1982) A regulatory pathway for fibrinogen biosynthesis involving an indirect feedback loop. Ann NY Acad Sci 389: 308

41. Goldberg M (1979) Dissertation, Stanford University, Stanford, CA

42. Goldberger G, Thomas ML, Tack BF, Williams J, Colten HR, Abraham GN (1981) $\mathrm{NH}_{2}$-terminal structure and cleavage of guinea pig proC 3 , the precursor of the third component of complement. $\mathrm{J}$ Biol Chem 256: 12617

43. Grace HJ, Brereton-Stiles GG, Vos GH, Shonland M (1976) A family with partial and total deficiency of complement C3. S Afr Med J 50: 139

44. Harper PS, Rivas ML, Bias WB, Hutchinson JR, Dyken PR, McKusick VA (1972) Genetic linkage 
confirmed between the locus for myotonic dystrophy and the ABH-secretion and lutheran blood group loci. Am J Hum Genet 24: 310

45. Harrison RA, Thomas ML, Tack BF (1981) Sequence determination of the thiolester site of the fourth component of human complement. Proc Natl Acad Sci USA 78: 7388

46. Hsieh K-H, Lin C-Y, Lee T-C (1981) Complete absence of the third component of complement in a patient with repeated infections. Clin Immunol Immunopathol 20: 305

47. Hugli TE (1975) Human anaphylatoxin (C3a) from the third component of complement: primary structure. J Biol Chem 250: 8293

48. Hugli TE (1981) The structural basis for anaphylatoxin and chemotactic functions of C3a, C4a and C5a. CRC Crit Rey Immunol 1: 321

49. Jacobs JW, Rubin JS, Hugli TE, Bogardt RA, Mariz IK, Davis JS, Daughaday WH, Bradshaw RA (1978) Purification, characterization and amino acid sequence of rat anaphylatoxin (C3a). Biochemistry 17: 5031

50. Karp DR, Shreffler DC, Atkinson JP (1982) Characterization of the $\mathrm{M}_{\mathrm{r}}$ difference between secreted murine fourth component of complement and the major plasma form: evidence for carboxylterminal cleavage of the $\alpha$ chain. Proc Natl Acad Sci USA 79: 6666

51. Khan SA, Erickson BW (1982) An equilibrium model of the metastable binding sites of $\alpha_{2}$ macroglobulin and complement proteins C3 and C4. J Biol Chem 257: 11864

52. Knowles BB, Howe CC, Aden DP (1980) Human hepatocellular carcinoma cell lines secrete the major plasma proteins and hepatitis B surface antigen. Science 209: 497

53. Kushner I (1982) The phenomenon of the acute phase response. Ann NY Acad Sci 389: 39

54. Kushner I, Edgington TS, Trimble C, Liem HH, Müller-Eberhard U (1972) Plasma hemopexin homeostasis during the acute phase response. J Lab Clin Med 80: 18

55. Lee JS, Trowsdale J, Travers PJ, Carey J, Grosveld F, Jenkins J, Bodmer WF (1982) Sequence of an HLA-DR $\alpha$-chain cDNA clone and intron-exon organization of the corresponding gene. Nature 299: 750

56. Malissen M, Malissen B, Jordan BR (1982) Exon/intron organization and complete nucleotide sequence of an HLA gene. Proc Natl Acad Sci USA 79: 893

57. Marder HK, Coleman TH, Forristal J, West CD (1982) Chronic glomerulonephritis associated with an inherited abnormality in $\mathrm{C} 3$ regulation. Kidney Int $21: 201$

58. Mauel J, Defendi V (1971) Infection and transformation of mouse peritoneal macrophages by simian virus 40. J Exp Med 134: 335

59. Mc Alpine PJ, Mohandas T, Ray M, Wang H, Hamerton JL (1976) Assignment of the peptidase D gene locus (PEPD) to chromosome 19 in man. Proceedings of the 3rd International Workshop on Human Gene Mapping, Baltimore, 1975. D. Bergsma (ed). Cytogenetics \& Cell Genetics, Vol. 16. Karger, p 204

60. McMaster GK, Carmichael GC (1977) Analysis of single and double-stranded nucleic acids on polyacrylamide and agarose gels by using glyoxal and acridine orange. Proc Natl Sci USA 74: 4835

61. Messing J, Crea R, Seeburg PH (1981) A system for shotgun DNA sequencing. Nucleic Acids Res 9 : 309

62. Milstein C, Brownlee GG, Harrison TM, Mathews MB (1972) A possible precursor of immunoglobulin light chains. Nature 239: 117

63. Mohr J (1954) A study of linkage in man (Opera Ex Biologiae Hereditariae Humanae Universitatis Hafniensis, 33). Munksgaard, Copenhagen

64. Morris KM, Aden DP, Knowles BB, Colten HR (1982) Complement biosynthesis by the human hepatoma-derived cell line Hep G2. J Clin Invest 70: 906

65. Morris, KM, Goldberger G, Colten HR, Aden DP, Knowles BB (1982) Biosynthesis and processing of a human precursor complement protein, Pro-C3, in a hepatoma-derived cell line. Science 215 : 399

66. Müller-Eberhard HJ (1975) Complement. Annu Rev Biochem 44: 697

67. Müller-Eberhard HA, Schreiber RD (1980) Molecular biology and chemistry of the alternative pathway of complement. Adv Immunol 29:1

68. Muschel RJ, Rosen N, Bloom BR (1977) Isolation of variants in phagocytosis of a macrophage-like continuous cell line. J Exp Med 145: 175

69. Natsuume-Sakai S, Hayakawa JI, Takahashi M (1978) Genetic polymorphism of murine C3 controlled by a single co-dominant locus on chromosome 17. J Immunol 121: 491 
70. Natsuume-Sakai S, Amano S, Hayakawa JI, Takahashi M (1978) Preparation of an alloantiserum to murine C3 and demonstration of multiple alleles. J Immunol 121: 2025

71. Natsuume-Sakai S, Moriwaki K, Amano S, Hayakawa JI, Kaidoh T, Takahashi M (1979) Allotypes of C3 in laboratory and wild mice distinguished by alloantisera. J Immunol 123: 216

72. Natsuume-Sakai S, Hayakawa JI, Amano S, Takahashi M (1979) Genetic mapping of the locus controlling structural variations of murine $\mathrm{C} 3$ in the chromosome 17. J Immunol 123: 947

73. Nonaka M, Natsuume-Sakai S, Kaidoh T, Nonaka M, Takahashi M (1980) Characterization of allotypic determinants of murine complement C3. J Immunol 125: 2025

74. Odink KG (1982) Studies on the expression of the genes for the third and fourth components of the complement system. Doctoral Dissertation, University of Wageningen, The Netherlands

75. Odink KG, Fey G, Wiebauer K, Diggelmann H (1981) Mouse complement components C3 and C4: characterization of their messenger RNA and molecular cloning of complementary DNA for C3. $\mathrm{J}$ Biol Chem 256: 1453

76. Osofsky SG, Thompson BH, Lint TF, Gewurz H (1977) Hereditary deficiency of the third component of complement in a child with fever, skin rash and arthralgias, and response to whole blood transfusions. J Pediatr 90: 180

77. Penalva da Silva F, Hoecker GF, Day NK, Vienne K, Rubinstein P (1978) Murine complement component 3: genetic variation and linkage to H-2. Proc Natl Acad Sci USA 75: 963

78. Porter RR, Reid KBM (1979) Activation of the complement system by antibody-antigen complexes: the classical pathway. Adv Protein Chem 33: 1

79. Propp RP, Alper CA (1968) C'3 synthesis in the human fetus and lack of transplacental passage. Science 162: 672

80. Proudfoot N, Brownlee GG (1976) 3' Non-coding region sequences in eucaryotic messenger RNA. Nature 263: 211

81. Pussell BA, Bourke E, Nayef M, Morris S, Peters DK (1980) Complement deficiency and nephritis: a report of a family. Lancet I: 675

82. Reid KBM, Porter RR (1981) The proteolytic activation systems of complement. Annu Rev Biochem 50: 433

83. Renwick JH, Bundey SE, Ferguson-Smith MA, Izatt MM (1977) Confirmation of linkage of the loci for myotonic dystrophy and ABH secretion. J Med Genet 8: 407

84. Rittner CH, Rittner B (1973) Third component of the human complement system: qualitative and quantitative comparison of C3 variant sera during the Bonn workshop. Vox Sang 25: 21

85. Roord JJ, Daha M, Kuis W, Verbrugh HA, Verhoef Y, Zegers BJM, Stoop JW (1983) Inherited deficiency of the third component of complement associated with recurrent pyogenic infections, circulating immune complexes, and vasculitis in a Dutch family. Pediatrics 71:81

86. Rubinstein P, Vienne K, Hoecker GF (1979) The location of the C3 and GLO (glyoxalase 1) loci of the IXth linkage group in mice. J Immunol 122: 2584

87. Ruddy S, Colten HR (1974) Rheumatoid arthritis: biosynthesis of complement proteins by synovial tissues. N Engl J Med 290: 1284

88. Scherrer K, Darnell JE (1962) Sedimentation characteristics of rapidly labeled RNA from HeLa cells. Biochem Biophys Res Commun 7: 486

89. Schreiber RD (1984) Complement receptors. Springer Semin Immunopathol 7: in press

90. Senger DR, Hynes RO (1978) C3 component of complement secreted by established cell lines. Cell 15: 375

91. Simola K, De La Chapelle A, Pirkola A, Karli P, Cook PJL, Tippett PA (1981) Data on DM-LE linkage. Human Gene Mapping 6 (1981), VI Inter-Workshop on Human Gene Mapping. Birth Defects 18: 2

92. Steinmetz M, Moore KW, Frelinger JG, Sher BT, Shen FW, Boyse EA, Hood L (1981) A pseudogene homologous to mouse transplantation antigens: transplantation antigens are encoded by eight exons that correlate with protein domains. Cell 25:683

93. Strunk RC, Tashjian AH, Colten HR (1975) Complement biosynthesis in vitro by rat hepatoma cell strains. J Immunol 114: 331

94. Sundsmo JS (1980) Expression of complement on human peripheral blood lymphocytes. Fed Proc 39: 1200

95. Tack BF (1983) The $\beta$-Cys- $\gamma$-Glu thiolester bond in human $\mathrm{C} 3$ and $\mathrm{C} 4$ Springer Semin Immunopathol 7: in press 
96. Tack BF, Morris SC, Prahl JW (1979) Third component of human complement: structural analysis of the polypeptide chains of $\mathrm{C} 3$ and $\mathrm{C} 3 \mathrm{~b}$. Biochemistry 18: 1497

97. Takahashi M, Kawachi-Takahashi S, Yamamoto K (1974) Synthesis of the ninth component of guinea pig complement (C9) in response to experimentally induced inflammation. Int Arch Allergy Appl Immunol 47: 887

98. Thomas ML, Janatova J, Gray WR, Tack BF (1982) Third component of human complement: localization of the internal thiolester bond. Proc Natl Acad Sci USA 79: 1054

99. Thomas ML, Janatova J, Gray WR, Tack BF (1982) Third component of human complement: localization of the internal thiolester bond. Proc Natl Acad Sci USA 79: 1054

100. Thompson EB, Tomkins GM, Curran JF (1966) Induction of tyrosine $\alpha$-ketoglutarate transaminase by steroid hormones in a newly established tissue culture cell line. Proc Natl Acad Sci USA 56:296

101. Thorbecke GJ, Hochwald GM, van Furth R, Müller-Eberhard HJ, Jacobsen EB (1965) Problems in determining the sites of synthesis of complement components. In: Wolstenholm GEW, Knight J (eds) Ciba Symposium 'complement'. Churchill, London, p 99

102. Tonegawa S, Maxam AM, Tizard R, Bernhard O, Gilbert W (1978) Sequence of a mouse germ-line gene of a variable region of an immunoglobulin light chain. Proc Natl Acad Sci USA 75: 1485

103. Vassalli JD, Hamilton J, Reich E (1976) Macrophage plasminogen activator: modulation of enzyme production by anti-inflammatory steroids, mitotic inhibitors, cyclic nucleotides. Cell 8: 271

104. Weigle WO, Morgan EL, Goodman MG, Chenoweth DE, Hugli TE (1982) Modulation of the immune response by anaphylatoxin in the microenvironment of the interacting cells. Fed Proc 41: 3099

105. Weitkamp LR, Johnston E, Guttormsen SA (1974) Probable genetic linkage between the loci for the Lewis blood group and complement C3. Cytogenet Cell Genet 13:183

106. Werb Z (1978) Biochemical actions of glucocorticoids on macrophages in culture: Specific inhibition of elastase, collagenase, and plasminogen activator secretions and effects on other metabolic functions. J Exp Med 147: 1695

107. Werb Z, Foley R, Munck A (1978) Glucocorticoid receptors and glucocorticoid-sensitive secretion of neutral proteinases in a macrophage line. J Immunol 121: 115

108. Whaley K (1980) Biosynthesis of the complement components and the regulatory proteins of the alternative complement pathway by human peripheral blood monocytes. J Exp Med 151: 501

109. Whitehead AS, Sim RB, Bodmer WF (1981) A monoclonal antibody against human complement component $\mathrm{C} 3$ : the production of $\mathrm{C} 3$ by human cells in vitro. Eur J Immunol 11: 140

110. Whitehead AS, Solomon E, Chambers S, Bodmer WF, Povey S, Fey GH (1982) Assingment of the structural gene for the third component of human complement to chromosome 19. Proc Natl Acad Sci USA 79: 5021

111. Wiebauer K, Domdey H, Diggelmann H, Fey G (1982) Isolation and analysis of genomic DNA clones encoding the third component of mouse complement. Proc Natl Acad Sci USA 79: 7077

112. Wieme RJ, Demulenaare B (1967) Genetically determined electrophoretic variant of the human complement component $C^{\prime} 3$. Nature 214: 1042

113. Winkelstein JA, Cork LC, Griffin DE, Griffin JW, Adams RJ, Price DL (1981) Genetically determined deficiency of the third component of complement in the dog. Science 212: 1169

114. Winkelstein JA, Johnson JP, Swift AJ, Ferry F, Yolken R, Cork LC (1982) Genetically determined deficiency of the third component of complement in the dog: In vitro studies on the complement system and complement mediated serum activities. J Immunol 129: 2598

115. Zardi L, Siri A, Carnemolla B, Cosulich E, Viale G, Santi L (1980) A simplified prodecure for the preparation of antibodies to serum fibronectin. J Immunol Methods 34: 155

\section{Note Added in Proof}

All DNA sequences given in this manuscript have been obtained by using the Maxam-and-Gilbert technique. Recent extensive studies by using the M13-Dideoxy sequencing technique have revealed two errors in the sequence given in Fig. 2. (Lundwall, Domdey, Gibson, Tack and Fey, manuscript in preparation). Comparison of these sequences with those of human alpha-2-macroglobulin (SottrupJensen, personal communication) by using the diagonal matrix computer program DIAGON (Staden 1982, Nucleic Acids Research 10: 2951) has revealed significant ( $\leq 26 \%$ ) sequence homologies in six regions of the beta- and alpha-chain of mouse $\mathrm{C} 3$ with human alpha-2-macroglobulin. 